\title{
Mapping the Link between Corporate Social Responsibility (CSR) and Human Resource Management (HRM): How Is This Relationship Measured?
}

\author{
Mónica Santana ${ }^{(D)}$, Rafael Morales-Sánchez ${ }^{(D)}$ and Susana Pasamar *(D) \\ Department of Management and Marketing, Universidad Pablo de Olavide; Carretera de Utrera, km. 1, \\ 41013 Seville, Spain; msanher@upo.es (M.S.); rmorsan@upo.es (R.M.-S.) \\ * Correspondence: spasrey@upo.es
}

Received: 5 February 2020; Accepted: 17 February 2020; Published: 24 February 2020

\begin{abstract}
Despite the relevance of human resources in the management of Corporate Social Responsibility (CSR), confusion and theoretical chaos are still evident in the area. This manuscript provides a systematic review of the link between CSR and Human Resource Management (HRM), stressing the main topics along with the evolution and tendencies founded in this field. SciMAT was used to conduct a conceptual science mapping analysis based on co-word bibliographic networks. From 2006 to 2019, 194 documents were retrieved from the Web of Science. Considering the last period (2017-2019), the motor themes (those which are well-developed and relevant for the structure of the research field) were environmental management (including green HRM), sustainable HRM and pro-environmental behaviour. Socially responsible HRM (SR-HRM) was a basic theme (important, although not developed). Perceived organisational support was a specialised theme (well-developed, although less important), and employee commitment was an emerging theme (both weakly developed and marginal). In addition, a review of the measurement tools used in the main topics extracted from the previous analysis was carried out. Our analysis will help inform researchers and practitioners on the future of CSR and HRM and the previous efforts in the creation of measurement instruments.
\end{abstract}

Keywords: CSR; human resource management; socially responsible human resource management; green human resource management; environmental management; sustainable human resource management; pro-environmental behaviour; SciMAT; bibliometrics

\section{Introduction}

The concept of Corporate Social Responsibility (CSR) has been tackled extensively in the literature, and it has generated a large number of academic publications, although it is also a subject of interest for companies. The European Commission [1] defined CSR as the process through which the social, environmental, ethical and human concerns of interest groups are integrated into business activities. These activities aim to maximize the creative value of these interest groups, as well as to identify, prevent or mitigate the negative influence of organisational actions on the environment [2].

However, despite the importance of the subject, widespread controversy, confusion and theoretical chaos are still evident as a consequence of the evolution of such a complex dynamic concept. So far, the CSR literature is inconsistent and lacks practical maturity [3,4], and one of the most relevant challenges involves the measurement of CSR, specifically from a human resource management (HRM) perspective.

Although recent efforts have been made to define and specify the particular activities included by the socially responsible HRM (SR-HRM) [2,4-6] label, there is still a need to improve the understanding 
of this discipline by founding instruments that effectively allow its evaluation and comparison in a systematic way [7], avoiding confusion with other topics.

This paper aims, firstly, to address the lack of structured analyses of the link between CSR and HRM in the literature and, secondly, to highlight motor and transversal themes, proposing emerging topics that are relevant for future research in the field. In that sense, this bibliometric research methodology provides a systematic review of the CSR-HRM field and contributes to the literature by identifying the most promising themes in this area, its evolution and its tendencies over time. Therefore, this paper poses two research questions: (1) what are the key topics that have been studied in the literature that link CSR and HRM and how have these research themes evolved; and (2) what are the main metrics used to capture this link? Consequently, this paper contributes to the literature by supplying a thorough and complete review of the work done regarding the instruments for measuring the different concepts related to CSR and HRM.

The paper is structured as follows: after this introduction, the next section provides an overview of the literature on the link between CSR and HRM; the third section explains the methodological approach used to analyse the field, bibliometrics and science mapping; the fourth section analyses the findings; finally, discussion and conclusions are presented.

\section{Theoretical Section}

There are many definitions of CSR and different ways of applying the concept. For the last decades, academics, politicians and business managers have discussed the scope of this corporate responsibility. CSR may mean different things to many people: what is understood as CSR has changed over time; it varies with region, country and culture; it is diverse for different types of organisations; and it is entirely in the eye of the paradigm beholder [3]. However, regardless of the different ways of understanding the responsibility of companies, the relationship with HR management can be specified in three ways: firstly, the company, in its strategic, tactical and operational development, impacts the nearby environment, mainly its employees. The company must take responsibility for this impact and, therefore, must try to know to what extent its corporate behaviour affects its workers. Secondly, each company is responsible for its impacts on its stakeholders. In that sense, one of the most important stakeholders is, again, the employees and, therefore, one of the first responsibilities of organisations is that on their employees, that is, to design and develop HR practices that specifically benefit their workers. Finally, the company's responsibility is concretized at a strategic level in specific objectives. These objectives can be determined in relation to the company's stakeholders or, in broader terms, referred to the three areas which CSR usually refers to: the economic, social and environmental areas. To achieve these strategic objectives, HR management is a key instrument for the proper deployment of CSR. Next, we will briefly describe each of these three forms of relationship between CSR and HRM.

\subsection{The Effect of CSR Practices on Employees}

CSR, regardless of its more or less strategic conception, is deployed in certain corporate practices that aim to achieve the objectives set by the organisation. These activities are not part of the HR strategy, although they may influence employees. Much of the research that analyses the relationship between CSR and HRM seeks to determine the effects of these CSR practices on workers. In this type of studies, CSR practices refer to a wide range of organisational behaviours; in particular, they refer to environmental and philanthropic practices [8], such as environmental protection and the development of local communities. It is not about SR-HRM practices, but about responsible practices that affect the company's HR. The focus is to show how these practices affect workers and whether that effect has a result on the behaviour of the workers and, ultimately, on their performance. Therefore, in these studies, it is usual to consider the perception of the employees toward CSR, rather than their perception toward the practices themselves. To analyse these perceptions, different scales have been developed in the literature, with those of Turker [9] being the most used scales. 
In addition, perceptions of CSR have been linked, firstly, to the attitudes of the employees, and then to their behaviours. Regarding the attitudes analysed in the literature, the most common have been worker satisfaction [10-12] and commitment to the organisation [9,12-18]. Regarding the behaviours observed, the attention devoted in the area to the organisational citizenship behaviour (OCB) $[14,19]$ stands out. OCB is defined as "individual behaviour that is discretionary, not directly or explicitly recognised by the formal reward system, and that in the aggregate promotes the effective functioning of the organisation" ([20], p. 4). Finally, some studies have focused on linking the perception of CSR directly or indirectly with the worker's performance. For example, Story and Castanheira [21] found the existence of a link between perceptions toward CSR and employee performance as rated by supervisors.

\subsection{The Organisation's Responsibility toward Its Employees}

One of the main responsibilities that a company must assume refers to its workers, as one of the main stakeholders, reflecting its relationship with them, and not only in terms of resources to obtain the highest performance [22]. Therefore, in response to the workers interests, the organisation may implement a socially responsible management of HR. This term "encompasses those policies and practices that contribute to improving the work and quality of life of employees, in accordance with the principles of CSR" [23]. The literature on SR-HRM has grown exponentially in recent years. However, far from having reached a consensus, there are currently different ways to determine which HR practices can be called socially responsible. One of the most widespread approach is to analyse the CSR or sustainability reports of companies to extract information on how CSR is managed toward workers. However, due to the differences between reports or CSR management systems, the practices are scarcely comparable. Another way of analysing SR-HRM is using questionnaires, arising different scales; unfortunately, there is no agreement on which one should be used [2].

\subsection{HR Management as a Tool to Achieve CSR Objectives}

To achieve organisational objectives, the company must manage its resources and capabilities in the most efficient way possible. The HR literature has demonstrated the importance of an adequate HR management strategy for the achievement of organisational objectives [24-27]. Therefore, when the social responsibility of the organisation is specified in economic, social and environmental objectives, HR management should be oriented toward achieving those objectives [8].

The ISO 26000 Social Responsibility standard states that "the objective of social responsibility is to contribute to sustainable development". Along the same lines, the European Union "encourages the private sector to contribute to the achievement of social and environmental objectives, thereby fostering equitable and sustainable growth and the protection of social rights" ([28], p. 11). In that sense, sustainable development is seen as "one that meets the needs of the present without compromising the ability of future generations to meet their own needs" ([29], p. 23). For companies, sustainable development is embodied in corporate sustainability, that is, "a business approach that creates long-term shareholder value by embracing opportunities and managing risks deriving from economic, environmental and social developments" [30]. There is increasing willingness for the largest companies to demonstrate their commitment to corporate sustainability because of the greater global public sensitivity [31].

Therefore, HR management is one of the organisational tools to achieve those sustainability objectives [32]. Companies have been adopting HR practices aligned with their strategic sustainability objectives and, to the same extent, new terms have emerged in the academic field to refer to those HR practices that aim to promote the sustainable behaviours of the organisation.

Two different HRM models related to environmental management should be differentiated, although they have been at times used interchangeably [33]: sustainable HRM and green HRM. Sustainable HRM is a set of HR strategies and practices to gain economic, social, and environmental objectives while simultaneously developing human capital in the long term [34]. Thus, sustainable HRM practices "are those practices that both enhance profit maximization for the organisation and also reduce the harm on 
employees, their families and communities" ([35], p. 104). On the other hand, green HRM "refers to using human resources management (HRM) practices to reinforce environmental sustainable practices and increase employee's commitment on the issues of environmental sustainability" ([36], p. 474). Green HRM could be considered as the HRM aspects of environmental management [37]. According to Ren et al. [38], green HRM pays attention only to the ecological aspect of organisational activities.

\section{Methods}

A systematic review through a co-word and co-citation analysis was conducted. Bibliometric methods explore the impact of a research field, a group of researchers, or a particular paper [39]. This study used science mapping, which provides a visual representation and a longitudinal evolution of the interrelations between scientific areas, documents or authors, reflecting its cognitive architecture [40,41].

We used SciMAT [42], which is a powerful open-source science mapping software tool. Based on co-word bibliographic networks [43], it offers science mapping but also performance analysis techniques which allow researchers to visualise and identify specific or general topics/themes and their thematic evolution. Consequently, it allowed us to detect and present conceptual subdomains in the link between CSR and HRM, as well as to track the conceptual evolution along time and the relevance of different topics related to this field of study. SciMAT incorporates all the tools necessary to carry out all the steps of the science mapping workflow, which helps to carry out the different steps of the science mapping workflow.

According to Börner et al. [44] and Cobo et al. [40], a science mapping analysis follows four different stages: data search, data refinement, network normalisation, mapping, analysis and visualisation and performance analysis.

In the first stage, the authors have to choose the online bibliographic database which is appropriate for the data search [45]. In our study, we used the Web of Science (WoS) database (www.webofknowledge.com), as it is the greatest comprehensive database in the field of the social sciences literature [46] and also offers the greatest coverage in years [47]. (see Table 1 for a summary of the journals which publish studies on the instruments for measuring the link between CSR and HRM themes).

Table 1. WoS Journals where the link between CSR and HRM research themes is published.

\begin{tabular}{clc}
\hline $\begin{array}{c}\text { Number of } \\
\text { Journals }\end{array}$ & \multicolumn{1}{c}{ Journal } & $\begin{array}{c}\text { 5-Year Impact } \\
\text { Factor (2018) }\end{array}$ \\
\hline 1 & SUSTAINABILITY & 2.801 \\
\hline 2 & JOURNAL OF CLEANER PRODUCTION & 7.051 \\
\hline 3 & INTERNATIONAL JOURNAL OF HUMAN RESOURCE MANAGEMENT & 3.457 \\
\hline 4 & CORPORATE SOCIAL RESPONSIBILITY AND ENVIRONMENTAL & 7.131 \\
\hline 5 & JANAGEMENT & 4.980 \\
\hline 6 & MANAGEMENT REVUE & ESCI \\
\hline 7 & ZEITSCHRIFT FUR PERSONALFORSCHUNG & 0.759 \\
\hline 8 & BUSINESS STRATEGY AND THE ENVIRONMENT & 7.557 \\
\hline 9 & JOURNAL OF ORGANIZATIONAL EFFECTIVENESS-PEOPLE AND & ESCI \\
\hline 10 & PERFORMANCE & ESCI \\
\hline 11 & BSIA-PACIFIC JOURNAL OF BUSINESS ADMINISTRATION & 3.423 \\
\hline 12 & HUMAN RESOURCE MANAGEMENT & 4.341 \\
\hline 13 & JOURNAL OF ORGANIZATIONAL BEHAVIOR & 6.533 \\
\hline 14 & HUMAN RESOURCE MANAGEMENT REVIEW & 4.704 \\
\hline
\end{tabular}


Table 1. Cont.

\begin{tabular}{clc}
\hline $\begin{array}{c}\text { Number of } \\
\text { Journals }\end{array}$ & Journal & $\begin{array}{c}\text { 5-Year Impact } \\
\text { Factor (2018) }\end{array}$ \\
\hline 15 & $\begin{array}{l}\text { INTERNATIONAL JOURNAL OF PRODUCTIVITY AND PERFORMANCE } \\
\text { MANAGEMENT }\end{array}$ & ESCI \\
\hline
\end{tabular}

Abbreviations: ESCI, Emerging Sources Citation Index; CSR, corporate social responsibility; HRM, human resource management; WoS, Web of Science.

The search was applied on articles and reviews available on WoS about management, business, environmental science, environmental studies, applied psychology, ethics, industrial labour and economics. The period of the analysis was the time horizon 2006-2019 (SciMAT did not find any research networks on instruments for measuring the link between CSR and HRM before 2006).

The keywords were the unit of analysis, allowing a longitudinal study of the CSR-HRM link. The keywords considered in the search were selected by consulting a group of expert researchers in the field and detecting keywords used previously in WoS articles. The final keywords are listed in Table 2.

Table 2. Keywords used to search the link between CSR and HRM in WoS.

TS $=\left(\right.$ "social* responsib* human resource* manage ${ }^{* \prime}$ or "social* responsib* human resource* practice" or "sustainable human resource* manage $e^{* \prime}$ or "sustainable human resource* practice" or "green human resource manage $^{* \prime}$ or "green human resource* practice" ${ }^{*}$ or "employee green behavio ${ }^{* \prime}$ or "o social* responsib* HRM" or "SR human resource* manage" or "SR human resource* practice" or "SR-HRM" or "SRHRM" or "sustainable HRM" or " green HRM" or "GHRM" or "Corporate Social Responsibility and human resource* manage*" or "CSR and human resource* manage $e^{* \prime}$ or "Corporate Social Responsibility and HRM" or "CSR and HRM" or "Corporate Social Responsibility and human resource* practice" or "CSR and human resource* practice ${ }^{* \prime}$ or "CSR and GRI" or "Corporate Social Responsibility and global reporting initiative" or "Corporate Social Responsibility and GRI" or "CSR and global reporting initiative" or "global reporting initiative and human resource* manage $e^{*}$ or "GRI and human resource* manage $e^{*}$ or "GRI and HRM" or "global reporting initiative and HRM" or "global reporting initiative and human resource* practice*" or "GRI and human resource ${ }^{*}$ practice*" or "corporate social responsib* and panel of expert")

Typing $(*)$ at the end of a word provides that word and all the words that share the same root.

The search protocol was applied on WoS, and the total number of publications returned from the searches was 194 peer-reviewed articles on instruments for measuring the CSR-HRM link up to 2019, distinguishing three different periods of time: 2006-2013; 2014-2016 and 2017-2019.

After this first step, the data were pre-processed in a second stage in order to detect duplicate and misspelled items or any other errors. The third stage consisted in the creation and normalisation of the network. A co-occurrence network was used, and afterward was filtered to discard non-representative items. Then, the items were standardised using the equivalence index. A clustering algorithm was implemented to get the map stage and the simple centre algorithm was used to obtain the science map and its clusters [48].

Once the maps were created, the analysis stage was initiated, which allowed us to detect and interpret the findings and connections from our data, research networks and maps. Four stages were established in order to analyse a research field in a longitudinal framework [39]:

(1) The corresponding academic topics were identified for every period of time by conducting a co-word analysis [49] for all the articles and reviews published in WoS in this research field, followed by a clustering of keywords around topics/themes [48]. This protocol search allowed us to identify highly related keyword nets and the topics that corresponded to the research problem of significant interest.

(2) In this stage, a visual representation of the themes and relationships was provided through two different graphical tools: strategic diagrams and thematic networks [39]. The strategic diagram shows the clusters detected for each period and categorises them according to their density and centrality [50]. While centrality measures the degree of interaction of a network with 
other networks and shows the importance of a theme in the development of the entire research field, density measures the internal strength of the network, and should be understood as the theme's development. Taking into account both concepts, a research field can be pictured as a set of themes. A strategic diagram could be built taking into account two dimensions and classifying topics into four different groups accordingly (see Figure 1): motor themes (upper-right quadrant; well-developed and important for the structure of the research field); specialised or peripheral themes (upper-left quadrant; well-developed but not relevant for the advance of the field); emerging or disappearing themes (lower-left quadrant; both weakly developed and marginal); and basic or transversal themes (lower-right quadrant; important for the research field, although not mature). The development of these themes along the considered period is also relevant to determine whether they are emerging or disappearing. The second graphical tool offered by SciMAT is the thematic network. A network graph represents the keywords in a research theme and their links (see [39]). The thematic networks are labelled according to the most central keyword in each net; we refer to a network graph as a cluster in this paper.

(3) The evolution of the field can be identified, analysing the development of the research themes over a specified period. SciMAT offers an evolution map [39], which shows the temporal evolution of research themes of the CSR-HRM link.

(4) This final stage allowed us to measure quantitatively and qualitatively the relative contributions of the research topics to the entire CSR-HRM literature, identifying the most relevant sub-fields. SciMAT builds science maps enriched with bibliometric indicators, such as number of published documents, citations, and different types of h-index.

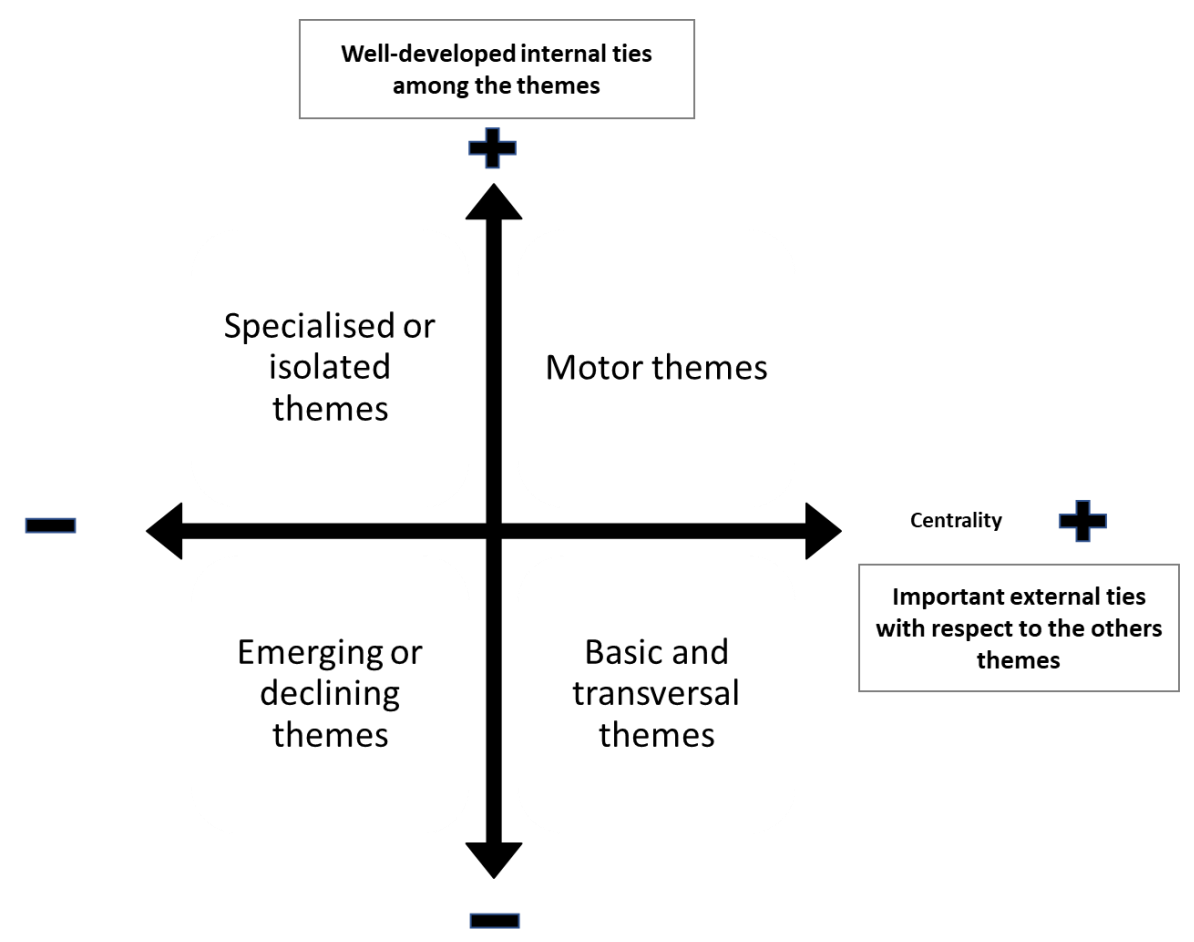

Figure 1. Strategic diagram.

\section{Results}

An increasing attention has been paid to the link between CSR and HRM in recent years. In the sub-period 2017-2019, 119 articles were published on this topic, significantly higher than in other years (2014-2016: 45 publications; or 2006-2013: 30 publications) (see Figure 2). 


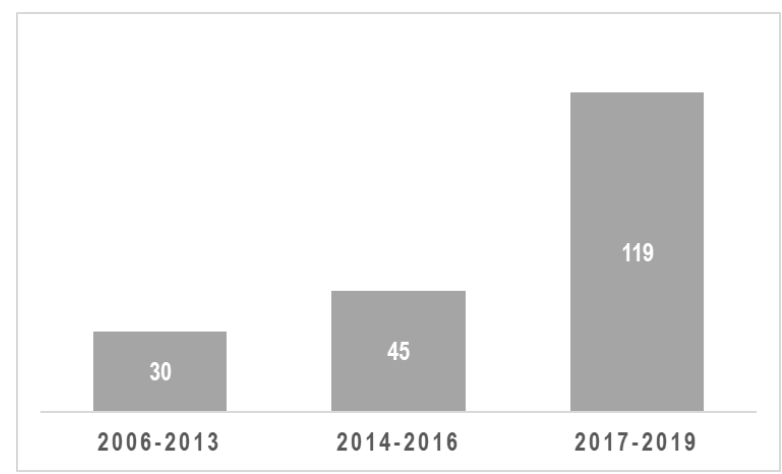

Figure 2. International WoS publications on instruments for measuring the CSR-HRM connection's field of study.

\subsection{Evolution of the CSR-HRM Link Themes}

Figure 3 illustrates the most important themes of the link between CSR and HRM along the periods 2006-2013, 2014-2016 and 2107-2019. Sphere size is related to the amount of documents associated to each research theme.

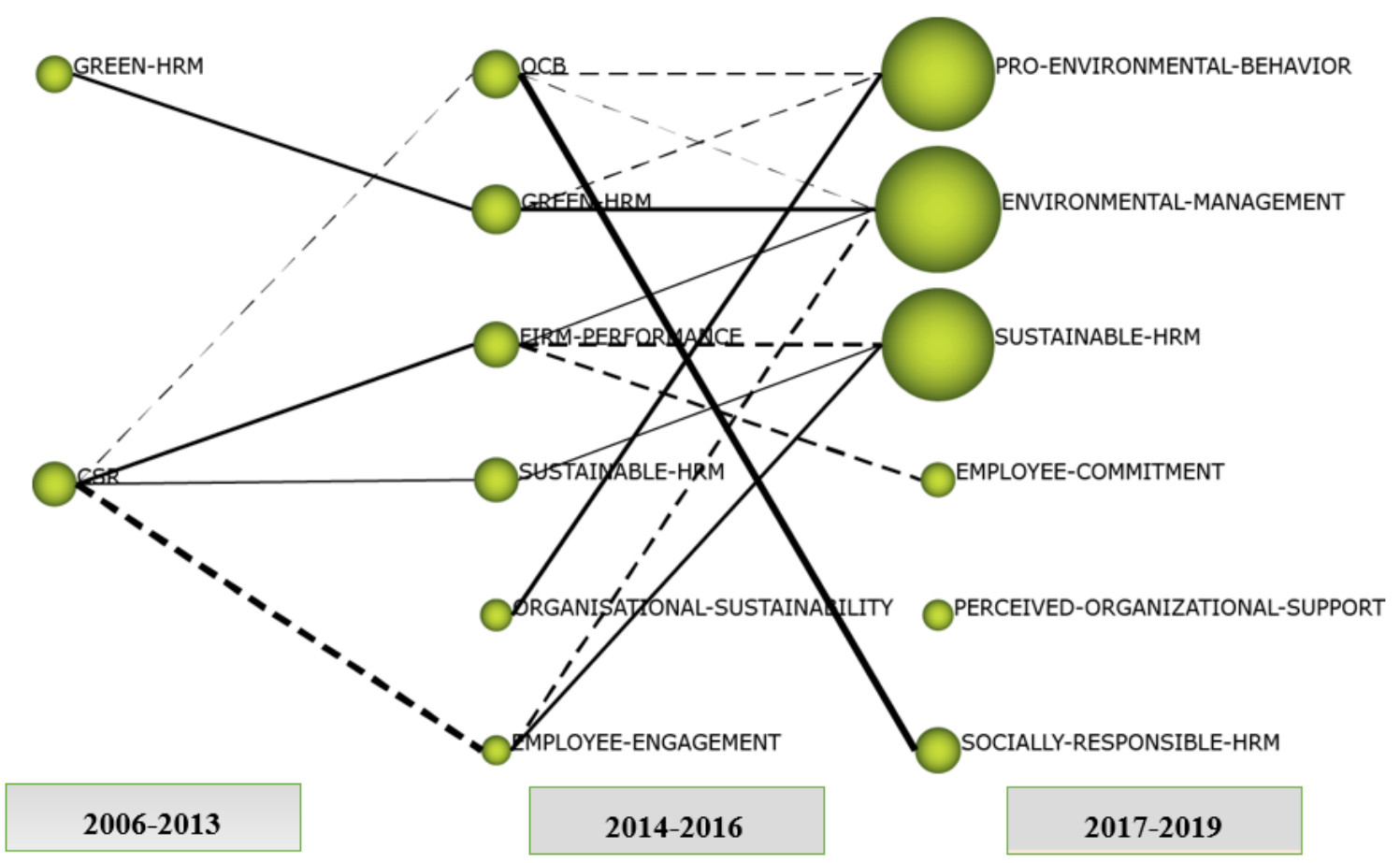

Figure 3. Evolution map of the instruments for measuring CSR's themes for the periods 2006-2013, 2014-2016 and 2017-2019.

The keywords differ in number and lexicography in the three sub-periods (2006-2013, 2014-2016, and 2017-2019) (Figure 3). The CSR-HRM link's terminology has evolved using different keywords to describe the content of the documents. In the sub-period 2017-2019, new topics gained relevance and appear as single research themes in the CSR-HRM link field of study (e.g., socially responsible HRM, sustainable HRM, environmental management, pro-environmental behaviour), while other research themes are incorporated into new related themes (e.g., green HRM, CSR). The CSR theme is included in the sustainable HRM theme and the green HRM theme in the environmental management theme. However, the socially responsible HRM theme gained its greatest relevance in the last sub-period, i.e., 2017-2019. Orlitzky and Swanson [51] coined the label "socially responsible HRM" in 2006. Later, 
different studies from fields such as CSR and ethics and organisational behaviour [52] incorporated the term SR-HRM [53].

On the other hand, research themes such as green HRM or sustainable HRM remained unchanged over two consecutive sub-periods, i.e., 2006-2013, 2014-2016, and 2014-2016, 2017-2019, respectively. In fact, green HRM gained special attention in 2011, when a Special Issue and its guest editors Jackson et al. [54] aimed to develop the green HRM literature. The process by which HRM must align its practices (such as recruiting, selection, performance evaluation and training) to environmental management objectives was called green HRM [54,55]. With respect to sustainable HRM, this research theme is becoming increasingly important, as reflected by seminal works [34,56,57]. Although previous research has devoted attention to corporate sustainability, the interest on its application to HRM and the necessary shift from short to long-term business success including not only finance aspects [58] is more recent.

\subsection{CSR-HRM Link Research Themes in Each Sub-Period}

We analyse in more detail each of the sub-periods.

\subsubsection{Sub-Period 2006-2013}

In the sub-period 2006-2013, the motor research themes (well-developed and important for the research field) of the link between CSR and HRM were CSR and green HRM (see Figure 4a). The CSR theme from 2006 to 2013 was associated with the performance, commitment, turnover, sustainable HRM, and ethics subthemes (see Figure $4 \mathrm{~b}$ ). The maintenance of current organisations does not solely rely on financial performance, as it must also consider multiple stakeholders' pressures to behave in a socially responsible manner [59]. Bučiūnienè and Kazlauskaite ([59], p. 5) added that "organisations with better developed HRM, where HR plays a more strategic role and its performance is more evaluated, also have more developed formal CSR policies, which in turn has a positive impact on organisational and financial performance outcomes". In fact, the integration of CSR and HRM has gained relevance; for instance, Lis [60] highlighted the importance of CSR for sustainable HRM and indicated that CSR has an impact on organisational attraction. She studied the importance of four CSR-dimensions to job seekers through a policy-capturing design. Furthermore, Bučiūnienè and Kazlauskaite [59] observed the links between formal CSR policies, implementation of CSR-related HR practices and performance outcomes, grounded on the Lithuanian data of the Cranfield Network of International Human Resource Management (CRANET) survey. Cooke and He [8] conducted a survey based on Carroll [61] and other CSR-related standards such as ISO 9000, as well as semi-structured interviews, to study CSR practices in Chinese textile and apparel companies, analysing the employee activities, environmental activities, marketplace activities, community activities, as well as company values and role of conduct. They concluded that companies focused on the market rather than on their employees when implementing CSR practices. Del Baldo [62] conducted a case study and highlighted that strong management's ethical foundations and commitment to share values and targets with their employees, underlie the effectiveness of the corporate family responsibility's practices. Shen and Zhu [53] found that the impact of perceived SR-HRM is, in general, positively related to organisational commitment. These seminal works on the relationship between CSR and HRM laid the foundations of the SR-HRM concept that would be developed in later years. 


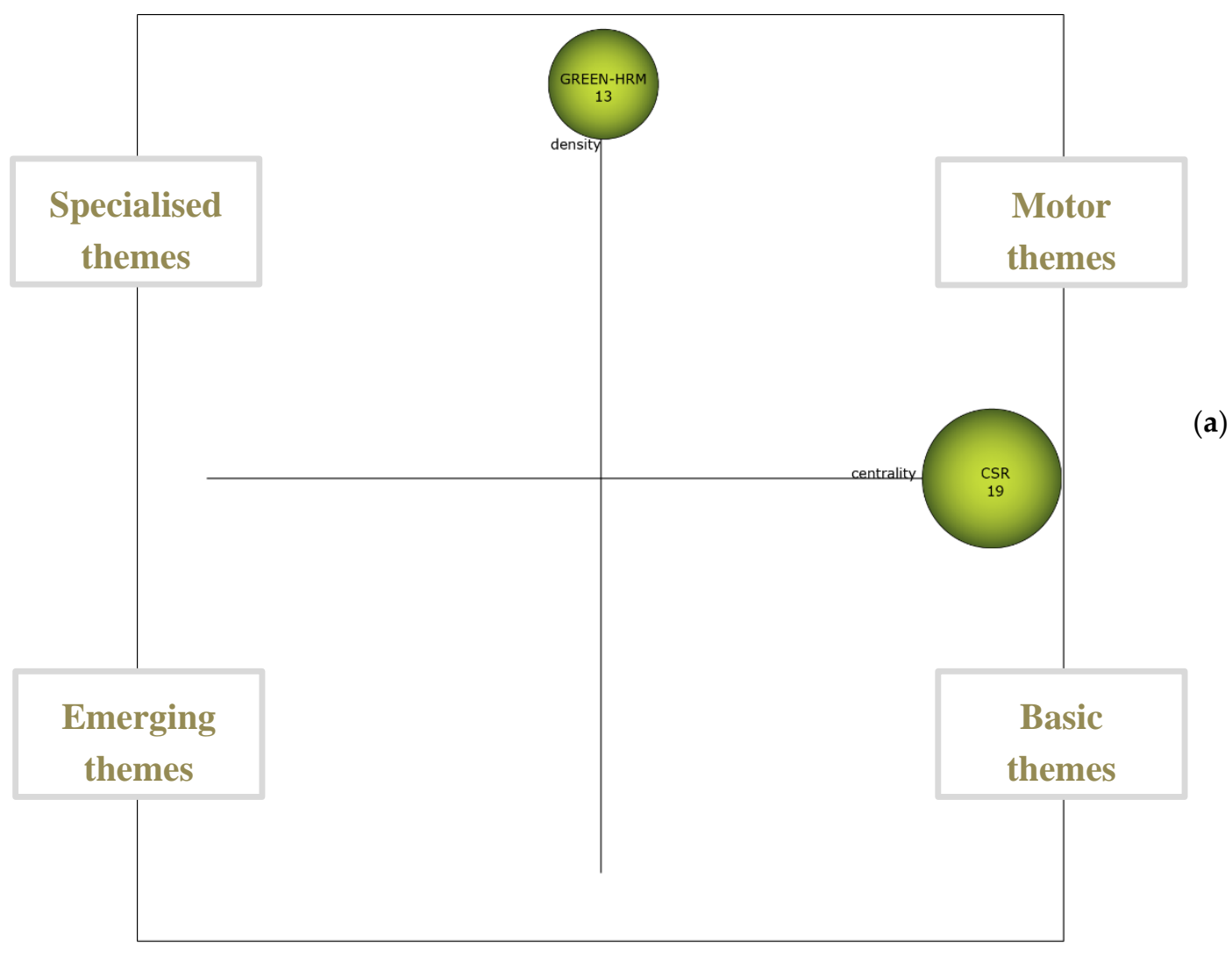

Figure 4. Cont. 


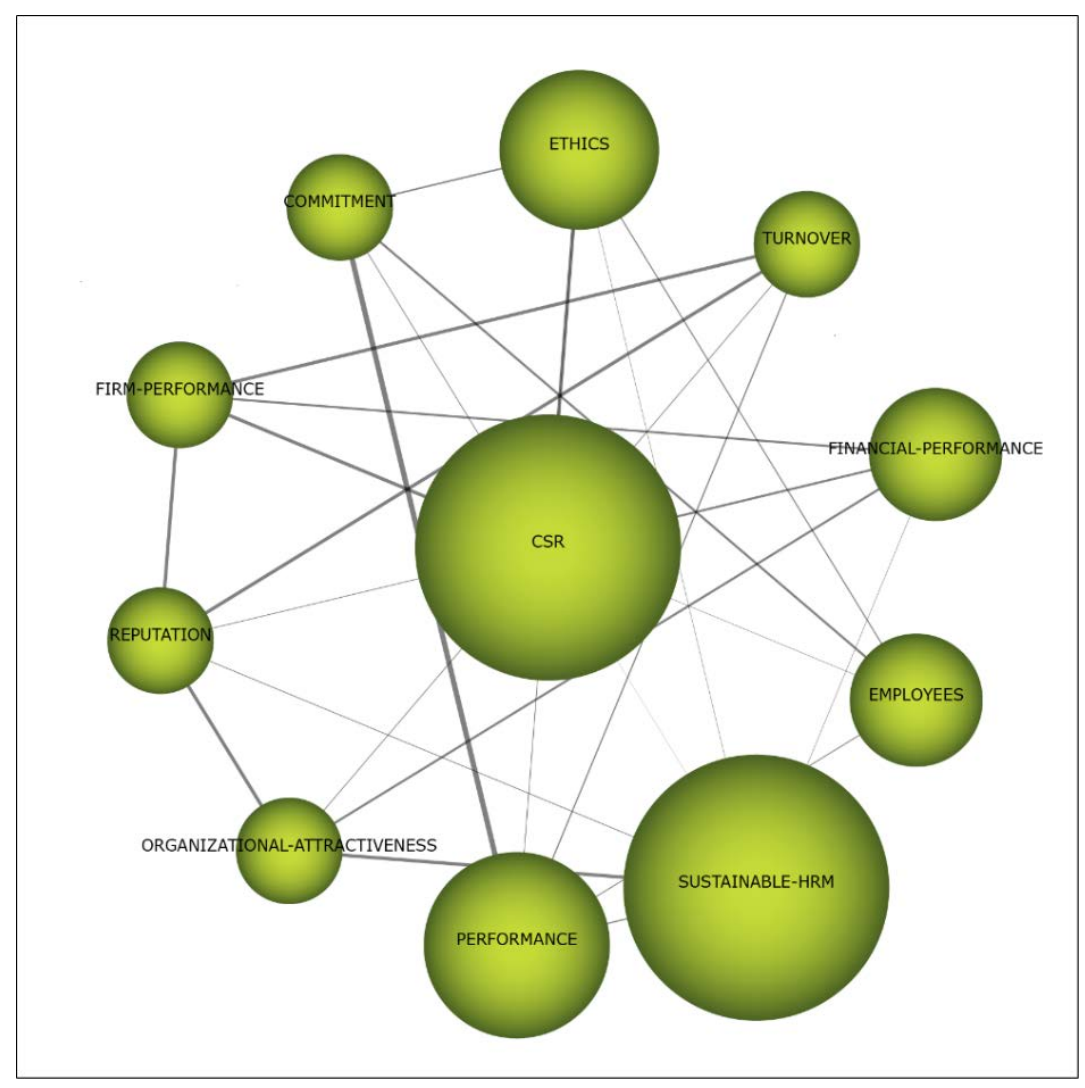

(b)

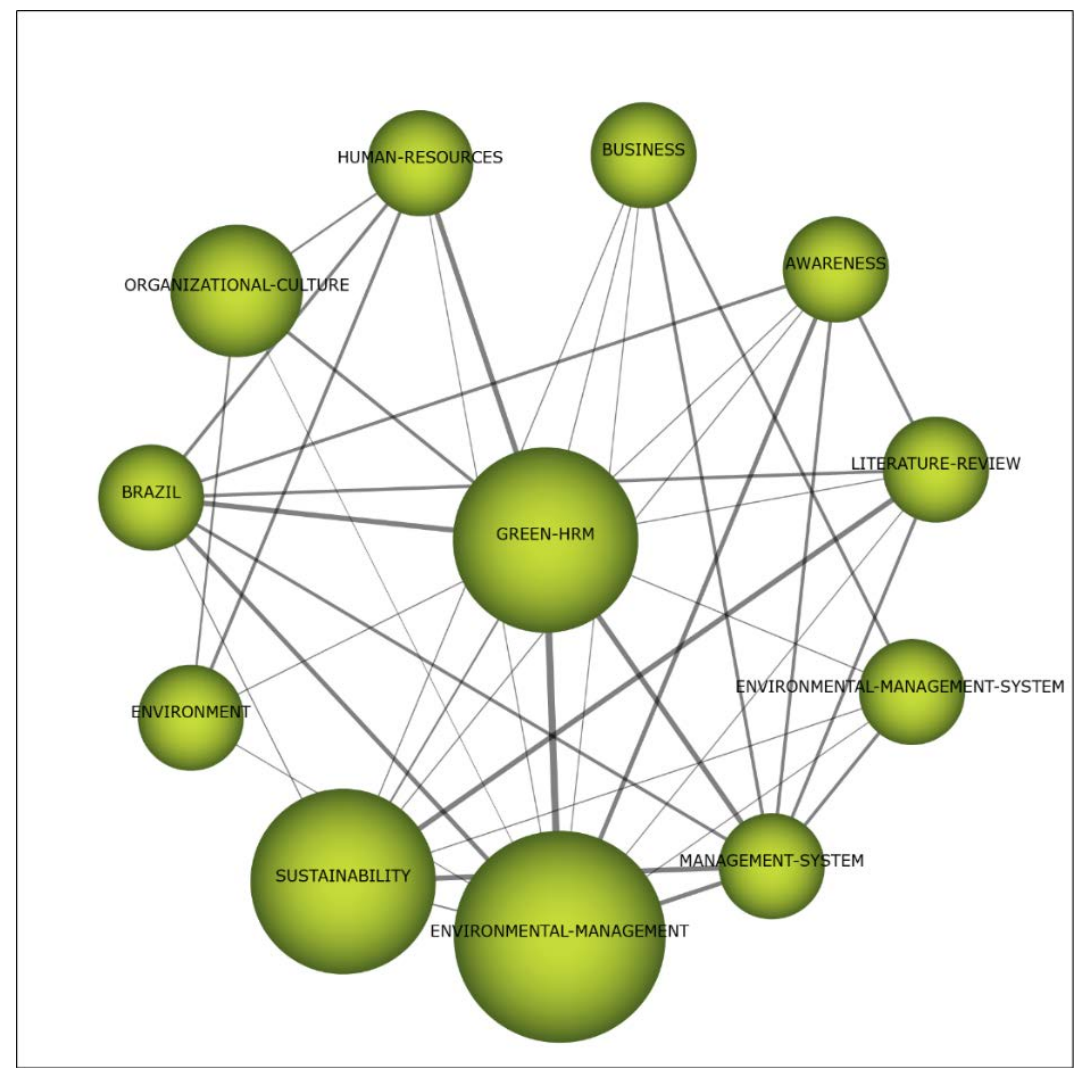

(c)

Figure 4. (a) Strategic diagram of instruments for measuring CSR's themes from 2006 to 2013. (b) Cluster's network of instruments for measuring the link between CSR and HRM's themes (CSR) for the period 2006-2013. (c) Cluster's network of instruments for measuring the link between CSR and HRM's themes (green HRM) for the period 2006-2013. 
The green HRM theme is linked to the environmental management and organisational culture subthemes (see Figure 4c). In fact, organisational culture has been found to be an important antecedent and indicator of environmental management success or failure within organisations [63]. Green HRM is considered as the HRM aspects of environmental management [37]. According to Renwick et al. [37] organisations should understand how green HRM practices affect employee motivation to accomplish environmental activities if they want to be effective in environmental management. These authors highlight the need to develop green abilities (through attraction, selection, training and development practices), motivate green employees (through performance management and compensation) and provide green opportunities (through employee involvement, empowerment and engagement, supportive culture and union role) within organisations. Jabbour et al. [64] studied the relationship between HRM and environmental management within 75 Brazilian companies using a survey strategy. The outcomes stated that HRM practices "tend to statistically significantly relate to environmental management in the analysed companies" ([64], p. 137). Wagner [65] studied the impact of environmental training activities for job satisfaction and employee retention/recruitment through two questionnaires implemented in 2001 and 2006. Thus, the link between HRM and environmental management flourished in that period.

\subsubsection{Sub-Period 2014-2016}

In the sub-period 2014-2016, the motor themes were organisational citizenship behaviour (OCB), green HRM, and sustainable HRM. Firm performance is a transversal or basic theme in the field of the link between CSR and HRM. Organisational sustainability and employee engagement are emerging themes in this field of study (see Figure 5a).

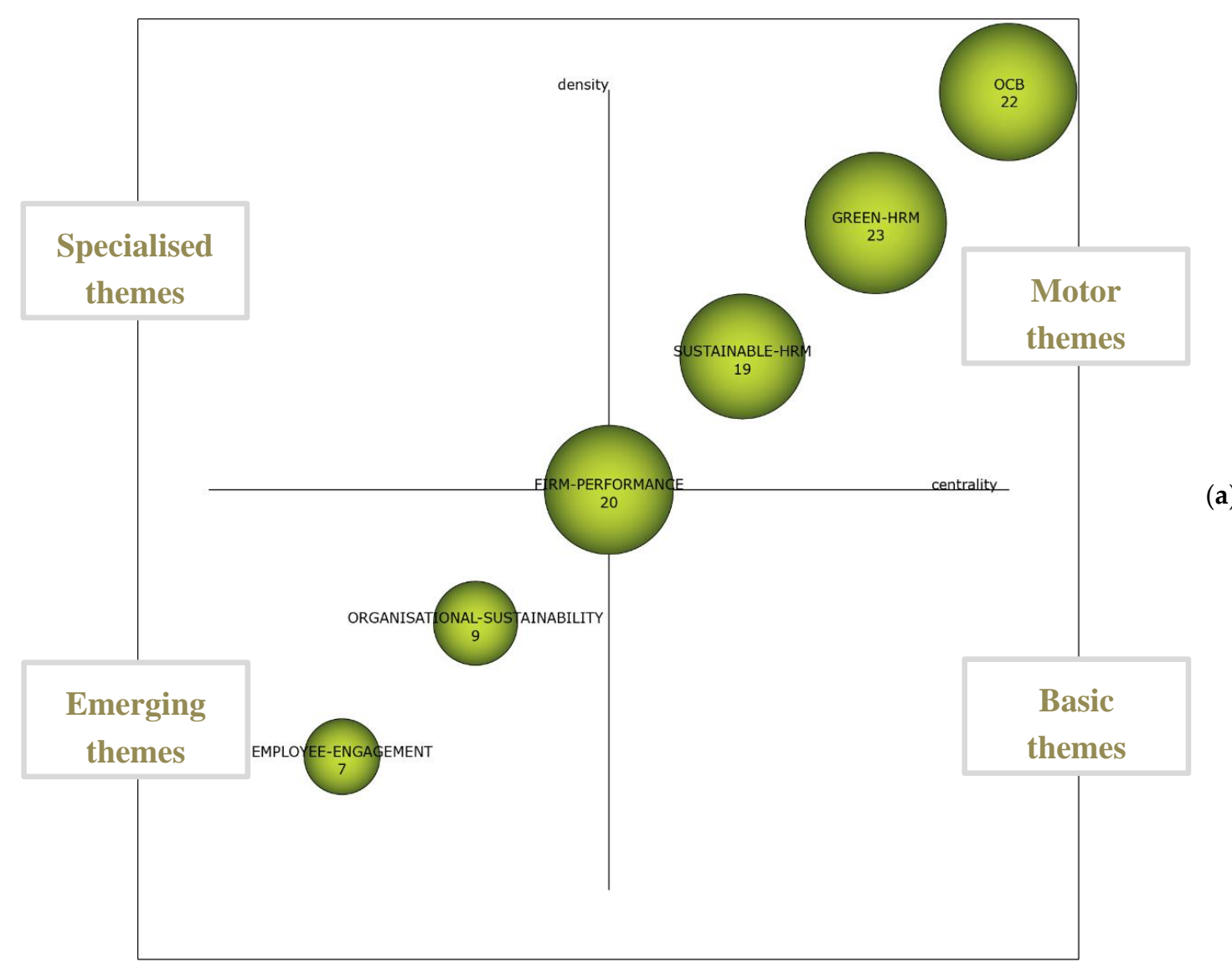

Figure 5. Cont. 


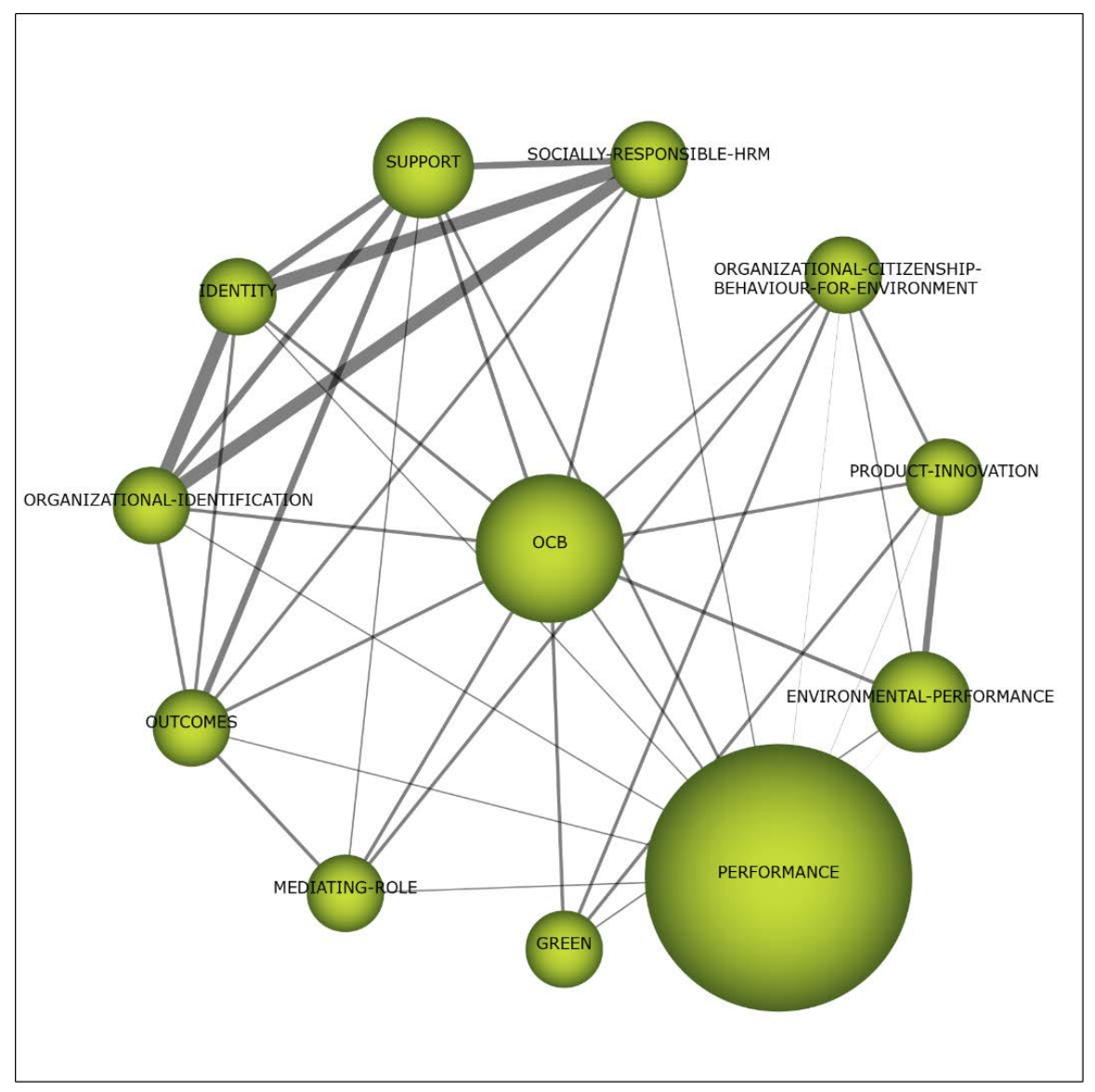

(b)

Figure 5. (a) Strategic diagram of instruments for measuring the link between CSR and HRM's themes from 2014 to 2016. (b) Cluster's network of instruments for measuring the link between CSR and HRM's themes (OCB) for the period 2014-2016.

OCB covers themes such as SR-HRM, organisational identification and organisational citizenship behaviour for the environment (OCBE), (see Figure 5b). Newman et al. [52] analysed the impact of SR-HRM on employee OCB. Shen and Benson [66] proposed and tested a 'meso-mediated' moderation model that studies the mechanisms through which employee task performance and extra-role behaviour are influenced by SR-HRM. Another theme related to the OCB research theme is OCBE. OCBE is a promising theme that captures pro-environmental behaviours in the workplace [67]. Paillé et al. [67] stated the mediation role that OCBE plays in the relationship between sustainable HRM and environmental performance, and that the influence of sustainable HRM on OCBE is determined by the internal environmental concern. OCBE is assessed by the scale developed by Boiral and Paillé [68].

Sustainable HRM is another motor theme in this field of study (see Figure 5a), and involve those strategies and practices related to the pursue of goals at different levels in the long term (social, economic and environmental) as well as improving human capital in the long term [34]. In this regard, it is relevant the comparative study conducted by Ehnert et al. [31], which paid attention to sustainability among the world's largest companies; Prins et al. [69] developed a Respect-Openness and Continuity model for sustainable HRM and Mariappanadar [70] created and validated a scale of health harm of work from the sustainable HRM. As previously stated, green HRM represents another motor theme in this period. The green HRM theme was further developed along 2014-2016 with relevant articles aimed to describe the relationship between green HRM and environmental performance [67], green HRM and green supply chain management [71] or the mediating role of green HRM practices [72], among other studies. 
Firm performance is a basic research subtheme of the sustainable HRM theme. In this sense, Lee and Maxfield [73] found that CSR and Global Reporting Initiative (GRI) have a positive impact on corporate environmental performance, and financial performance. Milfelner et al. [74] analysed the effect of social responsibility and HRM on firm performance, including growth, developmental and financial aspects. They highlighted that the relationship between HRM and firm performance has to be further developed in the future. In conclusion, in this subperiod, i.e., 2014-2016, the literature related to the CSR-HRM link has increased, as observed from the raising of the research themes and the number of documents (see Figures 2 and $5 a$ ).

\subsubsection{Sub-Period 2017-2019}

In the 2017-2019 sub-period, the motor themes were environmental management, sustainable HRM and pro-environmental behaviour. SR-HRM was a basic theme (important, although not developed). Employee commitment was an emerging theme (both weakly developed and marginal). Perceived organisational support (POS) was a specialised theme (see Figure 6a). As most of the publications regarding the link between CSR and HRM in this sub-period (see Figure 2), we focused on the profound analysis of the sub-period running from 2017 to 2019, to obtain rich and insightful results about these themes and tendencies. Moreover, the performance measures analysis (Table 3) shows the documents, citations and h-index per theme from 2017 to 2019.

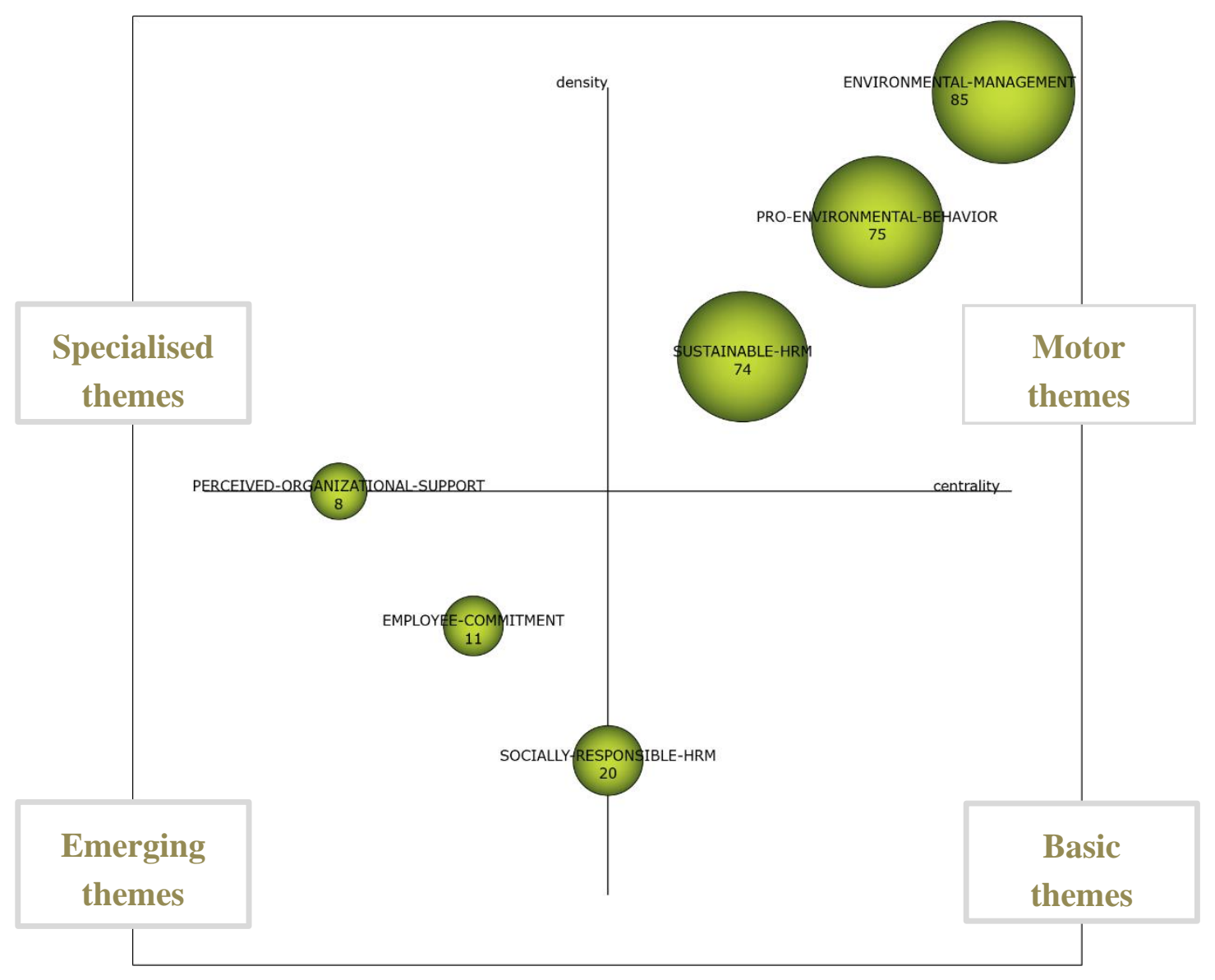

(a)

Figure 6. Cont. 


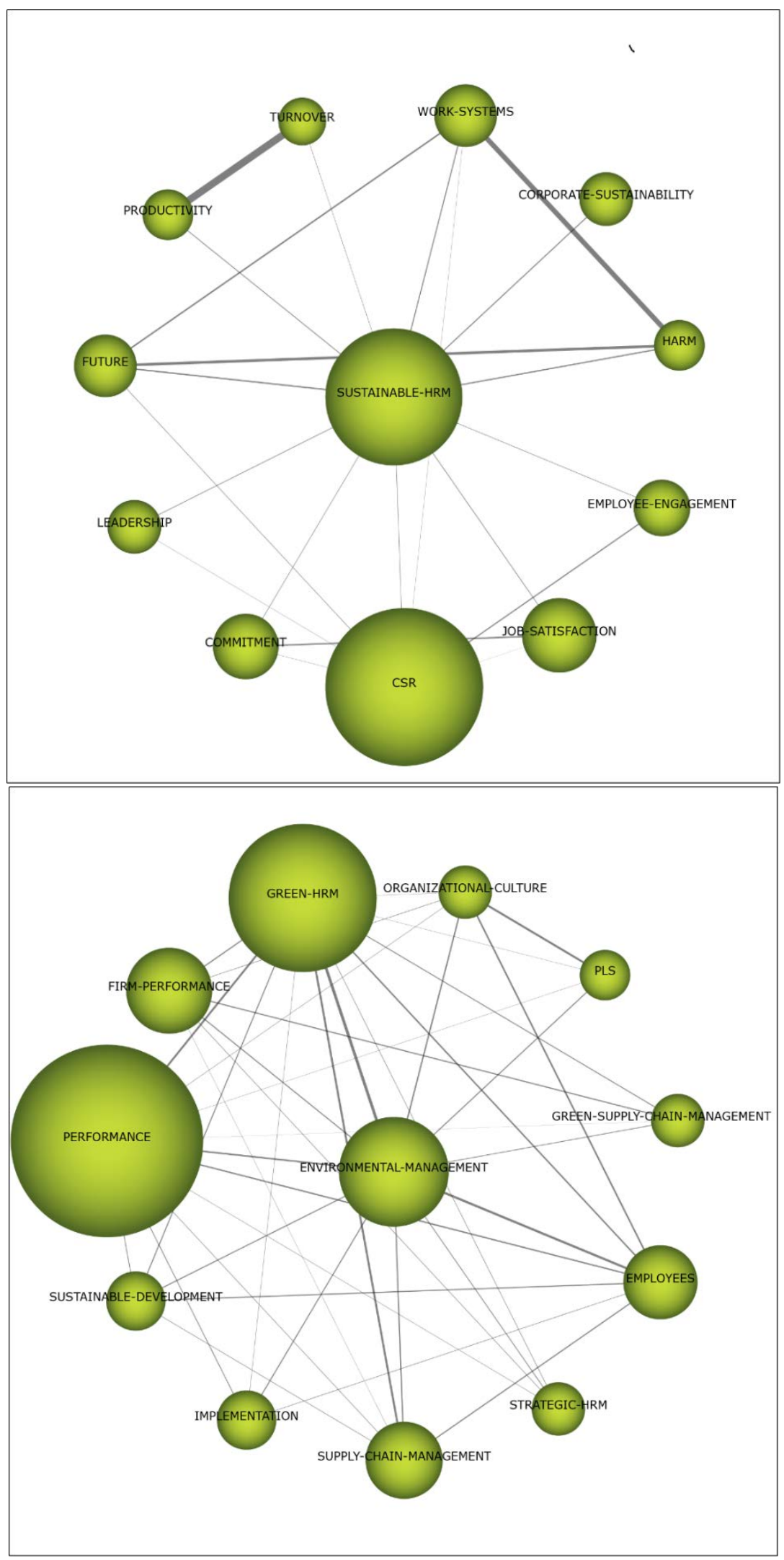

(b)

(c)

Figure 6. Cont. 


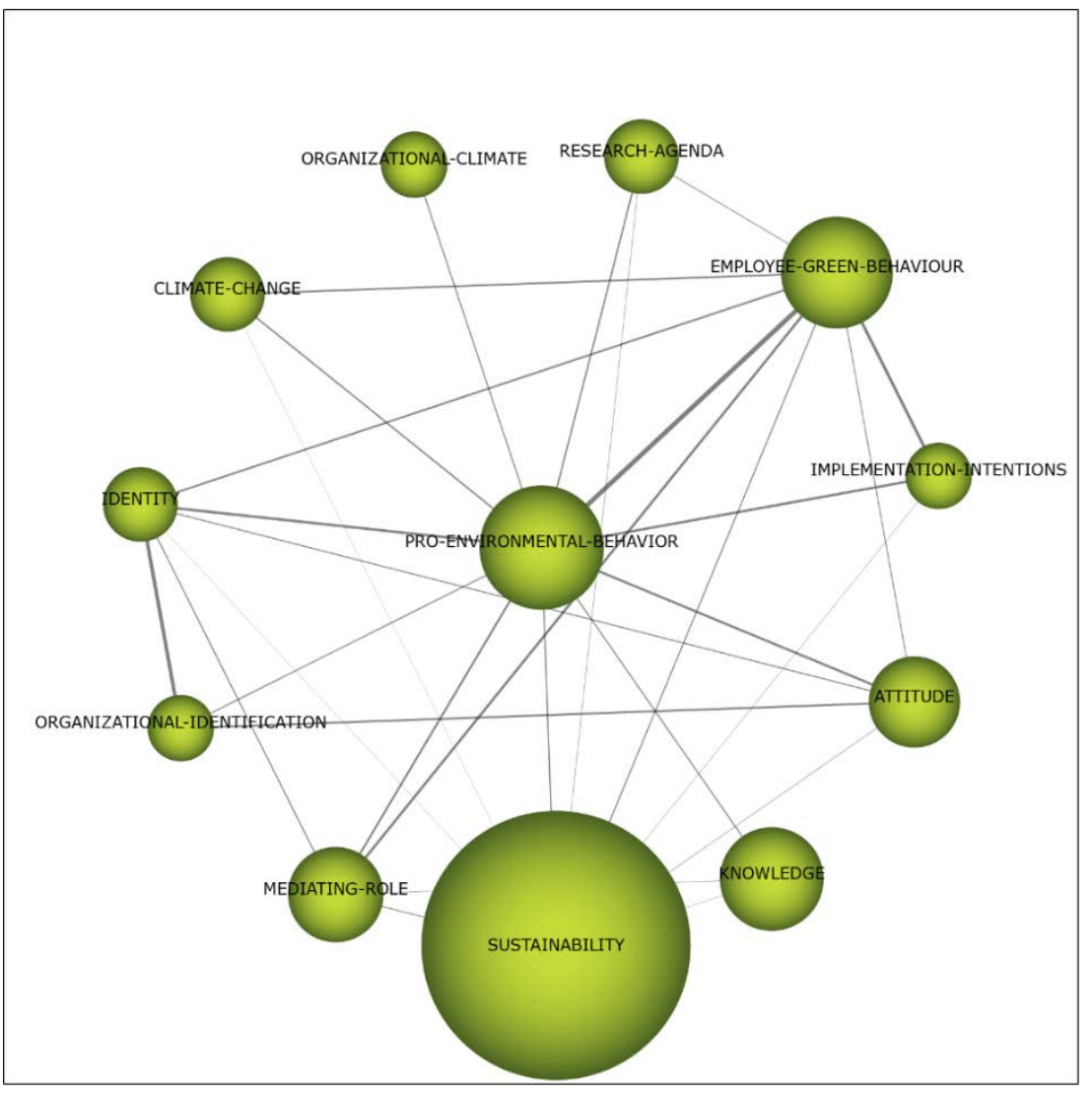

(d)

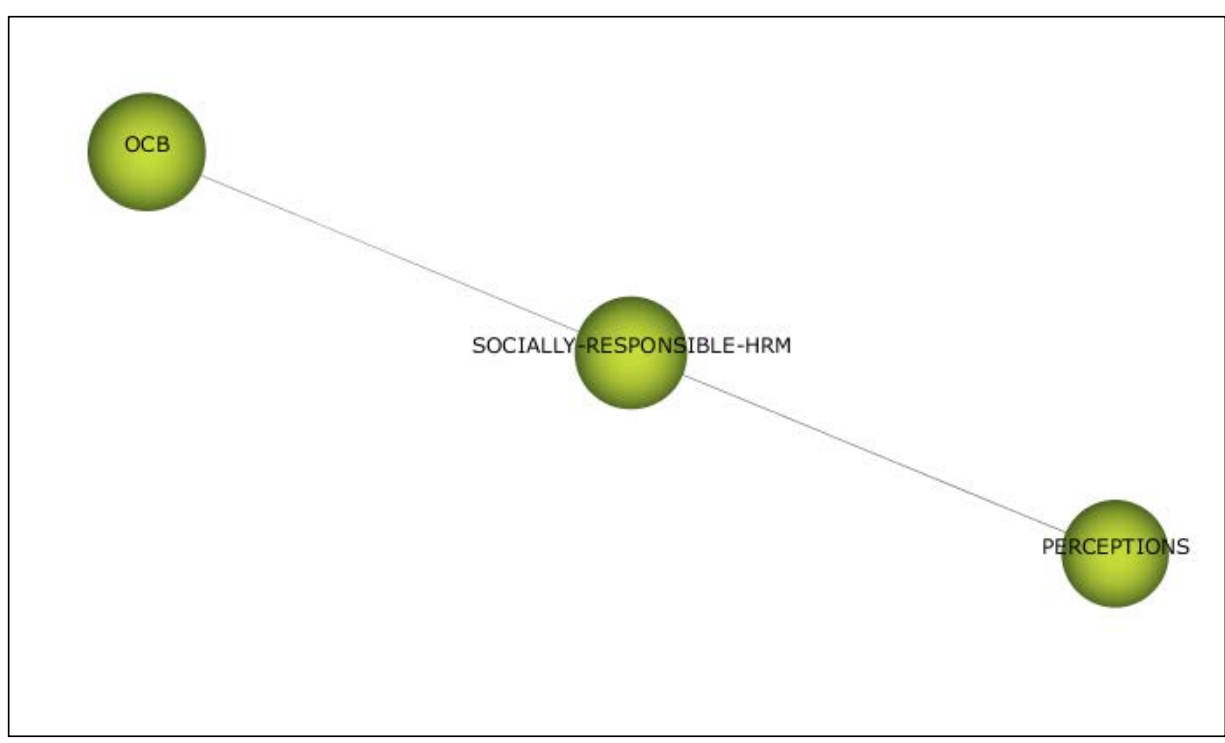

(e)

Figure 6. (a) Strategic diagram of instruments for measuring the CSR-HRM link's themes from 2017 to 2019. (b) Cluster's network of the instruments for measuring CSR's themes (Sustainable HRM) for the period 2017-2019. (c) Cluster's network of instruments for measuring CSR's themes (environmental management) for the period 2017-2019. (d) Cluster's network of instruments for measuring CSR's themes (pro-environmental behaviour) for the period 2017-2019. (e) Cluster's network of the instruments for measuring CSR's themes (socially responsible HRM) for the period 2017-2019. 
Table 3. Performance of the instruments for measuring CSR's themes for the period 2017-2019 (union documents).

\begin{tabular}{cccc}
\hline Name & Number of Documents & Number of Citations & H-Index \\
\hline Environmental management & 85 & 433 & 12 \\
\hline Pro-environmental behaviour & 75 & 356 & 11 \\
\hline Sustainable HRM & 74 & 310 & 10 \\
\hline Socially Responsible HRM & 20 & 81 & 4 \\
\hline Employee Commitment & 11 & 43 & 4 \\
\hline Perceived Organisational Support & 8 & 16 & 2 \\
\hline
\end{tabular}

In the period from 2017 to 2019 and in the field of study of the link between CSR and HRM, sustainable HRM was a motor theme (see Figure 6a). Sustainable HRM covers themes such as CSR, leadership and job satisfaction (see Figure 6b). Pellegrini et al. [75] studied how sustainable HRM practices can influence the employee behaviour to achieve corporate sustainability. They concluded that, when sustainability is important for the management, employees internalise the sustainability and show greater commitment to adopt a sustainable behaviour. Wang [76] studied a model that matches employees' job satisfaction, knowledge sharing, innovation capability, and job performance for sustainable HRM in hospitality context. With respect to CSR, which is a related subtheme in the sustainable HRM research theme, Lu et al. [22] empirically tested the connection between CSR specifically directed toward employees (CSRe) and career development sustainability. Although previous researchers have contributed to broaden the comprehension of the sustainable HRM concept, there is still a lack of research on how sustainable HRM is reflected through HR practices and how to measure this [77,78].

Furthermore, environmental management, with 85 documents and 433 citations, and pro-environmental behaviour, with 75 documents and 356 citations, were motor themes in this sub-period (well-developed and important) (see Table 3; Figure 6a). Environmental management covers themes such as green HRM, performance, sustainable development, organisational culture and green supply chain management (see Figure 6c). Pro-environmental behaviour includes themes such as organisational climate, sustainability and employee green behaviour (see Figure $6 \mathrm{~d}$ ). In previous periods, the role of HRM in environmental management gained interest [37,54]. In this period, the literature took a step further to analyse pro-environmental behavioural outcomes of HRM [79]. Thus, several researchers have analysed the impact of green HRM on different employee and organisation pro-environmental behaviour. For example, Longoni et al. [79] conducted a survey among HR and supply chain managers and highlighted that green HRM and green supply chain management influence the environmental and financial performance. Dumont et al. [80] found that green HRM directly impacted the in-role green behaviour, but indirectly affected the extra-role behaviour, through the mediation of psychological green climate. In addition, Saeed et al. [81] highlighted that green HRM practices positively impact the employee's pro-environmental behaviour, with the mediating role of the pro-environmental psychological capital and the moderating role of the employee's environmental knowledge.

Regarding SR-HRM, it represents a basic or transversal theme of the field of study of the link between CSR and HRM (see Figure 6a). SR-HRM covers research themes such as organisational citizenship behaviour and perceptions (see Figure 6e). Shen and Zhang [82] concluded that the link between SR-HRM and employee support for perceived external CSR is mediated by the organisational CSR climate. Shao et al. [83] concluded that perceived SR-HRM increases employees' organisational citizenship behaviour, although not task performance, through affective and cognitive mechanisms. In addition, Shao et al. [84] studied the effects of SR-HRM on employee performance, adding the moderator effect of prosocial motivation. López-Fernández et al. [23] found a link between SR-HRM and employee commitment, and that the employees' perceptions affect this relationship. Indeed, the 
concept of SR-HRM has recently been further developed [2,85], although more studies on the measures for the link between CSR and HRM are needed [86].

Employee commitment and perceived organisational support are variables that impact the link between CSR and HRM. Perceived organisational support (POS) is a specialised or peripheral topic (well-developed, although less important), with 8 documents and 16 citations (see Figure 6a; Table 3). Cugueró-Escofet et al. ([87], p. 2) consider POS as "a measure of efforts and contributions from the co-workers and the policies that demonstrate the interest and worries for the worker's wellbeing" and they used the scale developed by Aselage and Eisenberger [88] and Eisenberger et al. [89]. These authors concluded that POS, organisational justice and affective organisational commitment are positively related to knowledge sharing (one of the main elements to develop social sustainability), and they added that POS, job satisfaction and affective organisational commitment have a mediating role between organisational justice and knowledge sharing. Shen et al. [90] analysed the moderating role of perceived organisational support in the relationship between perceived green HRM and organisational identification. The employee commitment theme is not yet well-developed and marginal (see Figure 6a). Shen and Benson [66] highlighted the mediation role that employee commitment plays between SR-HRM and task performance. In that sense, Lechuga Sancho et al. [91] also considered that employee's commitment positively mediates the relationship between SR-HRM and the performance of small and medium enterprises. López-Fernández et al. [23] studied the influence of employees' perceptions toward SR-HRM on employee commitment. Indeed, employees prefer to share and cooperate in fair organisational contexts [87]. To summarise, in this sub-period 2017-2019, the literature on the link between CSR and HRM has flourished (see Figure 2; Table 3).

\section{Instruments for Measuring the CSR-HRM Link}

In this section we review the measurement tools of the main topics in the research on CSR and HRM: sustainable HRM, SR-HRM, green HRM and pro-environmental behaviours.

As stated earlier, the sustainable HRM concept is quite new and needs further conceptual and methodological development. Few studies have used validated scales of measurement. Some of the first studies used secondary data to analyse sustainable HRM. For example, Berber et al. [92] and Mariappanadar and Kramar [93] used the CRANET survey. Similarly, Ehnert et al. [31] analysed to what extent the Forbes top 250 global companies observe the GRI reporting guidelines in their sustainability reports.

More recently, Diaz-Carrion et al. [6] reviewed the sustainability reports of 194 firms and the main international CSR standards, and they conducted a Delphi study. They offered a sustainable HRM system by proposing an instrument for measuring CSR in the field of HRM and considering important institutional pressures from the European context and internationally accepted CSR standards with important implications for management. Moreover, Järlström et al. [94] highlighted the dimensions and responsibilities of sustainable HRM from the top managers' perspective through a qualitative study.

Pellegrini et al. [75] used different scales to measure sustainable behaviour, internal sustainability orientation, supervisory support, sustainability training, rewards, and affective commitment to sustainability. More recently, $\mathrm{Lu}$ et al. [22] tested social responsibility toward employees (CSRe = working benefit, working environment, working hours, and training) using a 16-item scale and career sustainability (career growth and employability), using the scales of Weng [95] and Rothwell and Arnold [96], respectively.

As Table 4 shows, there are many different instruments for measuring sustainable HRM. The lack of a clear terminology has led to uncertainty about how to assess sustainable HRM and what measures should be encompassed. 
Table 4. Dimensions used in the instruments for measuring sustainable HRM (2006-2019).

\begin{tabular}{cl}
\hline \multicolumn{1}{c}{ Original Article } & \multicolumn{1}{c}{ Dimensions/Practices } \\
\hline Madjar et al., (2011) [97] & Sustainable Creativity \\
\hline Lis (2012) [60] & Four CSR-dimensions: Product, Environment, Diversity, Employee relations \\
\hline Berber et al., (2014) [92] & Secondary Data: CRANET Database: Environmental matters, CSR and HRM \\
\hline Mariappanadar \& Kramar (2014) [93] & Secondary Data: CRANET Database: FHPWA, organizational performance \\
\hline Ehnert et al., (2016) [31] & Secondary Data: Global Reporting Initiative (GRI) \\
\hline Mariappanadar (2016) [70] & $\begin{array}{l}\text { Health harm of work scale. 3 dimensions: restrictions for positive health, risks factor for } \\
\text { psychological health, side effect of harm effect }\end{array}$ \\
\hline Esfahani et al., (2017) [98] & $\begin{array}{l}\text { HR sustainability (44 items). 3 dimensions: Work-life Balance, Personal Responsibility, } \\
\text { Employability }\end{array}$ \\
\hline Pellegrini et al., (2018) [75] & $\begin{array}{l}\text { Supervisory support: Ramus (2001) [99]. Sustainability training was measured using three } \\
\text { items from the study by Lytle et al., (1998) [100] and adapting its wording to the field of } \\
\text { corporate sustainability. Rewards were assessed using two items adapted from Lytle et al., } \\
\text { (1998) [100]. }\end{array}$ \\
\hline Diaz-Carrion et al., (2018) [6] & $\begin{array}{l}\text { A system of sustainable HRM formed by six policies and 98 practices. Content analysis of } \\
\text { the sustainability reports of 194 companies and the most used standards (GRI, OSP 26000, } \\
\text { OSHAS18001, SA8000 and UNGC). A Delphi study validated the scale. }\end{array}$ \\
\hline Strenitzerova \& Achimsky (2019) [101] & $\begin{array}{l}\text { HRSI (Human Resource Satisfaction Index) } \\
\text { Manzoor et al., (2019) [102] }\end{array}$ \\
$\begin{array}{l}\text { Five dimensions: Selection, Training, Participation, Employee empowerment, Job } \\
\text { performance }\end{array}$ \\
\hline
\end{tabular}

Regarding SR-HRM, as previously stated, the term was originally defined by Orlitzky and Swanson [51]. In this seminal work, the following HR practices were analysed: recruitment and selection, performance appraisal, compensation, and training and development. Later, many of the studies that measured SR-HRM used the scale originally developed by them (see Table 5). For example, Shen and Benson [66] composed a 6-item measure from that scale. In turn, Shen and Zhang [82] measured SR-HRM practices following Shen and Benson's [66] six-factor scale and statistically validated it in the Chinese context.

Table 5. Dimensions used in the instruments for measuring SR-HRM (2006-2019).

\begin{tabular}{|c|c|c|}
\hline Original Article & Dimensions/Practices & Used By \\
\hline Cooke \& He (2010) [8] & $\begin{array}{l}\text { Four CSR practices: employee activities environmental activities, } \\
\text { marketplace activities, community activities }\end{array}$ & \\
\hline Shen \& Zhu (2011) [53] & $\begin{array}{l}\text { Three-component model: legal compliance-HRM, employee } \\
\text { oriented-HRM, general CSR facilitation-HRM. }\end{array}$ & $\begin{array}{l}\text { Newman et al., } \\
\quad(2016)[52]\end{array}$ \\
\hline $\begin{array}{c}\text { Bučiūnienè \& } \\
\text { Kazlauskaitė (2012) [59] }\end{array}$ & CRANET survey & \\
\hline $\begin{array}{l}\text { Shen \& Benson } \\
\text { (2016) [66] }\end{array}$ & $\begin{array}{l}\text { HR practices adapted from Orlitzky and Swanson (2006) [51]: } \\
\text { recruitment and selection, performance appraisal, compensation, } \\
\text { training and development }\end{array}$ & $\begin{array}{l}\text { Shen \& Zhang (2019) [82] } \\
\text { Shao et al., (2019) [84] } \\
\text { Shao et al., (2019) [83] }\end{array}$ \\
\hline $\begin{array}{l}\text { Barrena-Martínez et al., } \\
\text { (2017) [2] }\end{array}$ & $\begin{array}{l}\text { Eight HR policies (and } 32 \text { practices): Attraction and retention of } \\
\text { employees, Training and continuous development, Management of } \\
\text { employment relations, Communication, transparency and social } \\
\text { dialogue, Diversity and equal opportunities, Fair remuneration and } \\
\text { social benefits, Prevention, health and security at work, } \\
\text { Work-family balance }\end{array}$ & $\begin{array}{l}\text { Lopez-Fernandez et al., } \\
\text { (2018) [23] }\end{array}$ \\
\hline $\begin{array}{l}\text { Obrad \& Gherhes } \\
\quad(2018) \text { [103] }\end{array}$ & $\begin{array}{l}\text { Five dimensions (and } 23 \text { indicators): Working conditions, Health and } \\
\text { workplace safety, Professional development and training, Employees' } \\
\text { rights, Internal communication }\end{array}$ & \\
\hline $\begin{array}{l}\text { Lechuga Sancho et al., } \\
\qquad(2018)[99]\end{array}$ & $\begin{array}{l}\text { Five dimensions (and } 16 \text { items): Training and continuous development, } \\
\text { Work-life balance, Attention to diversity, Communication, Professional } \\
\text { career }\end{array}$ & \\
\hline Nie et al., (2018) [104] & $\begin{array}{l}\text { Two dimensions (and } 11 \text { items): Equal career opportunity practices, } \\
\text { Work-family integration practices }\end{array}$ & \\
\hline $\begin{array}{l}\text { Barrena-Martinez et al., } \\
\quad \text { (2018) [105] }\end{array}$ & $\begin{array}{l}\text { It indicates the extent to which the company incorporates CSR (ethical, } \\
\text { social, human, and labour concerns) into HRM }\end{array}$ & \\
\hline $\begin{array}{l}\text { Bombiak \& } \\
\text { Marciniuk-Kluska } \\
\quad(2018)[106]\end{array}$ & 35 practices identified pursuant to the analysis of source literature & \\
\hline
\end{tabular}


As the investigation in SR-HRM progressed, other measurement scales have been proposed in the literature. Shen and Jiuhua Zhu [53] developed the term SR-HRM proposing a three-component model that differentiates between legal-compliance HRM, employee-oriented HRM and general CSR-facilitation HRM. Specifically, legal compliance was measured through six items: equality, compliance with labour laws regarding health and safety, minimum wage, working hours, no use of child or forced labour and appointing adequate employees to monitor labour standards in the global value chain. Equality had four sub-components: recruitment and selection, training and development, performance appraisal and reward and compensation. Employee-oriented was measured using four items: flexible working hours and employment programmers for achieving work-life balance; adequate training and development opportunities; workers' organisations participating in determining labour terms; and employee involvement and participation. To measure general CSR facilitation, they proposed three items: appointing CSR staff; appraising and rewarding employees' contribution to CSR; and giving priority of employment to candidates with family difficulties or who had been fired, and to local candidates in order to contribute to the sustainability of local economies and societies.

Recently, Barrena-Martínez, et al. [2] validated their own instrument for measuring SR-HRM. The content analysis included a review of the literature, CSR reports, and international CSR standards such as the Global Reporting Initiative and ISO 26000. Afterward, the theoretical findings were supported by a panel of experts who reached a significant agreement after three rounds of reviews. Their results support the existence of a configuration of eight SR-HRM policies divided into practices. Table 6 shows the main instruments for measuring SR-HRM.

Table 6. Dimensions used in the instruments for measuring green HRM (2006-2019).

\begin{tabular}{|c|c|c|}
\hline Original Article & Practices/Dimensions/Subscales & Used By \\
\hline $\begin{array}{l}\text { Jabbour et al., } \\
(2010)[107]\end{array}$ & $\begin{array}{l}\text { Nine dimensions: Job analysis and description, Recruitment, Selection, } \\
\text { Training, Performance appraisal, Rewards, Group articulation, } \\
\text { Corporate cultural management, Corporate learning management }\end{array}$ & Saeed et al., (2019) [81] \\
\hline Renwick et al., (2013) [37] & $\begin{array}{l}\text { AMO model: Developing green abilities (Attracting/selecting; Training } \\
\text { \& Development), Motiving green employees (Performance } \\
\text { management/appraisal; Pay and reward systems), Providing green } \\
\text { opportunities (Employee involvement; Supportive climate/culture; } \\
\text { Empowerment and engagement; Union role in employee involvement } \\
\text { and environmental management) }\end{array}$ & \\
\hline $\begin{array}{l}\text { Zibarras and Coan } \\
\quad(2015)[108]\end{array}$ & $\begin{array}{l}\text { Five dimensions: Employee life cycle, Rewards, Education and training, } \\
\text { Employee empowerment, Manager involvement }\end{array}$ & Zhang et al., (2019) [109] \\
\hline $\begin{array}{l}\text { O'Donohue and Torugsa } \\
\text { (2016) [110] }\end{array}$ & $\begin{array}{l}\text { AMO model: Developing green abilities (Environmental training for } \\
\text { employees), Motivating green employees (investing in people; creation } \\
\text { of good work-life balance and family-friendly employment; improving } \\
\text { employee health and safety), Providing green opportunities (employee } \\
\text { participation in decision-making process) }\end{array}$ & \\
\hline Guerci et al., (2016) [72] & $\begin{array}{l}\text { Three dimensions: Green hiring, Green training and involvement, } \\
\text { Green performance management and compensation }\end{array}$ & \\
\hline Gholami et al., (2016) [33] & $\begin{array}{l}\text { Seven dimensions: Union role in environmental involvement and } \\
\text { management, Training and development, Attraction and selection, } \\
\text { Culture and supportive climate, Pay and reward, Performance } \\
\text { management, Involvement and empowerment }\end{array}$ & \\
\hline Dumont et al., (2017) [80] & $\begin{array}{l}\text { Six items (My company sets green goals for its employees; My company } \\
\text { provides employees with green training to promote green values; My } \\
\text { company provides employees with green training to develop } \\
\text { employees' knowledge and skills required for green management; My } \\
\text { company considers employees' workplace green behaviour in } \\
\text { performance appraisals; My company relates employees' workplace } \\
\text { green behaviours to rewards and compensation; My company considers } \\
\text { employees' workplace green behaviours in promotion) }\end{array}$ & $\begin{array}{l}\text { Chaudhary (2019) [111] } \\
\text { Ahmad \& Umrani } \\
\text { (2019) [112] }\end{array}$ \\
\hline Tang et al., (2018) [113] & $\begin{array}{l}\text { Five dimensions: Training, Performance, Pay and reward, Involvement, } \\
\text { Recruitment and selection }\end{array}$ & Chaudhary (2019) [111] \\
\hline Bombiak (2019) [114] & $\begin{array}{l}\text { Seven areas of human resource policy: Green job design and analysis, } \\
\text { Green recruitment, Shaping of green discipline at work, Green } \\
\text { development, Green performance evaluation, Green motivation, Green } \\
\text { HRM procedures }\end{array}$ & \\
\hline
\end{tabular}


Table 6. Cont.

\begin{tabular}{clc}
\hline \multicolumn{1}{c}{ Original Article } & \multicolumn{1}{c}{ Practices/Dimensions/Subscales } & Used By \\
\hline Chaudhary (2019) [111] & $\begin{array}{l}\text { 21 items taken from Tang et al. [113] and Dumont et al. [80]. Six } \\
\text { practices: Green Involvement, Green Pay \& Reward, Green Performance } \\
\text { Management, Green Training, Green Recruitment \& Selection }\end{array}$ \\
\hline & $\begin{array}{l}\text { Seven dimensions: Green job design (seven items); Green recruitment } \\
\text { and selection (17 items); Green training and development (16 items); } \\
\text { Green performance management (13 items); Green compensation } \\
\text { Shah (2019) [115] } \\
\text { magement (12 items); Green health and safety (three items); Green } \\
\text { involvement and labour relations (16 items) }\end{array}$ \\
\hline
\end{tabular}

One of the most used green HRM scales was developed by Jabbour et al. [107], identifying nine dimensions of green HRM: job analysis and description; recruitment; selection; training; performance appraisal; rewards; group articulation; corporate cultural management; and corporate learning management. Other researchers constructed a green HRM measure with four dimensions: employee life cycle, rewards, education and training, and employee empowerment [108]. Furthermore, Guerci, et al. [72] developed a green HRM measure to assess green hiring, green training and involvement, and green performance management and compensation. Tang, et al. [113] have also recently elaborated and validated a green HRM practices scale, and Saeed et al. [81] measured five green HRM practices with the scale of Jabbour, et al. [107].

Like sustainable HRM, green HRM is a very young area of study and is still immature. In 2018, Ren et al. [38] conducted a review on conceptualization, theoretical foundations and measurement of green HRM. Regarding how to assess green HRM, they concluded that "for the field of green HRM to advance, research efforts must focus on developing psychometrically sound measures that assess clearly defined constructs" (p. 784). Some instruments for measuring green HR management can be found in Table 6.

Finally, regarding pro-environmental behaviour, Saeed et al. [81] measured the Pro-environmental psychological climate using the scale of Chou [116]; the pro-environmental behaviour scale was obtained from three studies [117-119]. Table 7 shows the main instrument for measuring it.

Table 7. Dimensions used for measuring pro-environmental behaviour (2006-2019).

\begin{tabular}{|c|c|c|}
\hline Original Article & Dimensions/Practices & Used By \\
\hline $\begin{array}{l}\text { Boiral and Paille } \\
\text { (2012) [68] }\end{array}$ & $\begin{array}{l}\text { Organizational Citizenship Behaviour for the Environment. Three } \\
\text { dimensions: Eco-initiatives (three items): Discretionary behaviour and } \\
\text { suggestions to improve environmental practices or performance; Eco-civic } \\
\text { engagement (four items): Voluntary participation in an organization's } \\
\text { environmental programmes and activities; Eco-helping (three items): } \\
\text { Voluntarily helping colleagues to better integrate environmental concerns in } \\
\text { the workplace }\end{array}$ & $\begin{array}{l}\text { Paillé et al., (2013) [120] } \\
\text { Paille \& Raineri } \\
\text { (2016) [121] } \\
\text { Priyankara et al., } \\
\text { (2018) [122] } \\
\text { Pinzone et al., } \\
\text { (2019) [123] }\end{array}$ \\
\hline $\begin{array}{l}\text { Bissing-Olson et al., } \\
\text { (2013) [124] }\end{array}$ & $\begin{array}{l}\text { Daily Employee Green Behaviour: Daily task-related pro-environmental } \\
\text { behaviour (three items): adapted from Williams and Anderson's (1991) } \\
\text { adding the phrase "in environmentally friendly ways" to each item; Daily } \\
\text { proactive pro-environmental behaviour at work (three items): adapted from } \\
\text { Frese et al. [125] adding the words "at work," "environmental protection," } \\
\text { "environmentally friendly ways," and "for the environment" to each item. }\end{array}$ & $\begin{array}{l}\text { Norton et al., (2014) [126] } \\
\text { Chaudhary (2019) [111] } \\
\text { Zhang et al., (2019) [109] }\end{array}$ \\
\hline Graves et al., (2013) [127] & Pro-environmental behaviours (13 items) & Kim et al., (2016) [118] \\
\hline Lamm et al., (2013) [128] & Organizational Citizenship Behaviour Toward the Environment (12 items) & Islam et al., (2019) [129] \\
\hline Markle (2013) [130] & $\begin{array}{l}\text { Pro-Environmental Behaviour Scale. Four dimensions: Conservation (seven } \\
\text { items); Environmental citizenship (six items); Food (three items); } \\
\text { Transportation (three items) }\end{array}$ & Prati et al., (2017) [131] \\
\hline $\begin{array}{l}\text { Robertson and Barling } \\
\text { (2013) [119] }\end{array}$ & Workplace Environmentally Friendly Behaviour (seven items) & $\begin{array}{l}\text { Bin Saeed et al., } \\
\text { (2019) [81] }\end{array}$ \\
\hline Kim et al., (2017) [132] & Voluntary Workplace Green Behaviour (six items) & \\
\hline Norton et al., (2017) [133] & $\begin{array}{l}\text { Daily Employee Green Behaviour (five items): "Thinking about your work } \\
\text { today, to what extent did you? conserve water; recycle; avoid waste; save } \\
\text { energy; use resources efficiently" }\end{array}$ & \\
\hline $\begin{array}{l}\text { Xing and Starik } \\
\text { (2017) [134] }\end{array}$ & $\begin{array}{l}\text { Employee green behaviour. Qualitative data: in-depth narrative interviews } \\
\text { with managers and employees in different industries in China }\end{array}$ & \\
\hline
\end{tabular}


Table 7. Cont.

\begin{tabular}{cl}
\hline Original Article & \multicolumn{1}{c}{ Dimensions/Practices } \\
\hline $\begin{array}{c}\text { Bohlmann et al., } \\
\text { (2018) [135] }\end{array}$ & $\begin{array}{l}\text { Employee green behaviour scenarios: printing double-sided; recycling } \\
\text { behaviour; switching off electronic devices in order to save energy }\end{array}$ \\
\hline $\begin{array}{c}\text { Rayner \& Morgan } \\
\text { (2018) [136] }\end{array}$ & $\begin{array}{l}\text { Green Behaviours. Two dimensions: Green work behaviours (three items); } \\
\text { Green home behaviours (three items) }\end{array}$ \\
\hline Zoogah (2018) [137] & Green Behaviours (six items) \\
\hline Paille et al., (2019) [138] & Non-green behaviours (six items) \\
\hline $\begin{array}{c}\text { Bin Saeed et al., } \\
\text { (2019) [81] }\end{array}$ & $\begin{array}{l}\text { Pro-environmental behaviour (16 items) adapted from Kaiser et al. [117]; } \\
\text { Robertson and Barling [119]; and Kim et al. [118] }\end{array}$ \\
\hline Zhang et al., (2019) [139] & $\begin{array}{l}\text { Implementation of Green Operational Practices (4 items) adapted from Rao } \\
\text { and Holt [140] and Gonzalez et al. [141]. }\end{array}$ \\
\hline
\end{tabular}

\section{Discussion and Conclusions}

The present study contributes to the development of the CSR literature analysing its link to HRM by presenting a bibliometric analysis and a systematic review that helps to clarify the field. Firstly, it highlights the most promising themes and trends for the future; secondly, this study also addresses the lack of structured analyses of the instruments for measuring the CSR-HRM literature.

Therefore, our study may have implications for researchers, practitioners and public administrations. Our findings may guide them on future steps to be taken, as it offers a critical evaluation thereof and a vision of the highest impact research strands. This paper offers researchers the opportunity to position their future studies, offering them the latest avenues of research. A conceptual science mapping analysis based on co-word bibliographic networks has been developed. According to the last period analysed (2017-2019), the motor themes (well-developed and important) identified by the instrument for measuring CSR were environmental management, sustainable human resource management (HRM) and pro-environmental behaviour. SR-HRM was a basic or transversal theme (important for the field of study, although not developed). Perceived organisational support was a specialised theme (well-developed, although less important for the structure of the research field), and employee commitment was an emerging theme (both weakly developed and marginal to the field) in the CSR-HRM field.

Our findings indicate that there is still an apparent confusion of terms, and the absence of consensus regarding the instruments for measurement has been also highlighted. More deliberation and decision-making should take place in order to avoid uncertainty. Future research should tackle the lack of consistency in the measuring instruments highlighted in our results. Practitioners and researchers should develop additional work for a better understanding of CSR and its connection with HRM, avoiding confusion and inconsistencies. Future studies should also focus on the direct effects of the link between CSR and HRM, explaining the moderating and mediating role that other variables may play in this relationship.

This study is not without limitations. This research only considered documents from management, business, environmental science, environmental studies, applied psychology, ethics, industrial labour and economics. Nevertheless, these areas embody the main literature regarding CSR and its relationship with HRM. Additionally, this study has retrieved articles and reviews from the WoS and thus, it restricts the research to the approach of the documents included in this database. This paper may have excluded research published outside of WoS journals, although the fact that WoS represents the world's leading academic database in social science [142] adds value to this research. Moreover, the document selection was grounded on certain WoS categories, and some researches could be included in other categories [143]. In addition, some authors do not mention all the relevant keywords (in fact, the oldest documents do not include keywords), or there may be some bias in the keywords to use. However, a strong point of SciMAT is the possibility of refining the keywords in order to obtain more accurate results. 
Author Contributions: Conceptualization, M.S., R.M.-S. and S.P.; methodology and software, M.S.; writingreview and editing M.S., R.M.-S. and S.P. All authors have read and agreed to the published version of the manuscript.

Funding: This work was supported by Research Group, grant number PAIDI 2019.SEJ602.

Acknowledgments: We would like to thank Manuel Cobo for his always valuable support.

Conflicts of Interest: The authors declare no conflict of interest.

\section{References}

1. European Commission. Communication from the Commission to the European Parliament, the Council, the European Economic and Social Committee and the Committee of the Regions: A Renewed EU Strategy 2011-14 for Corporate Social Responsibility; 2011. Available online: https://www.europarl.europa.eu/meetdocs/2009_ 2014/documents/com/com_com(2011)0681_/com_com(2011)0681_en.pdf (accessed on 19 December 2019).

2. Barrena-Martínez, J.; López-Fernández, M.; Romero-Fernández, P.M. Towards a configuration of socially responsible human resource management policies and practices: Findings from an academic consensus. Int. J. Hum. Resour. Manag. 2019, 30, 2544-2580. [CrossRef]

3. Voegtlin, C.; Greenwood, M. Corporate social responsibility and human resource management: A systematic review and conceptual analysis. Hum. Resour. Manag. Rev. 2016, 26, 181-197. [CrossRef]

4. Jamali, D.R.; El Dirani, A.M.; Harwood, I.A. Exploring human resource management roles in corporate social responsibility: The CSR-HRM co-creation model. Bus. Ethics A Eur. Rev. 2015, 24, 125-143. [CrossRef]

5. Dupont, C.; Ferauge, P.; Giuliano, R. The Impact of Corporate Social Responsibility on Human Resource Management: GDF SUEZ's Case. Int. Bus. Res. 2013, 6, 145-155. [CrossRef]

6. Diaz-Carrion, R.; López-Fernández, M.; Romero-Fernandez, P.M. Developing a sustainable HRM system from a contextual perspective. Corp. Soc. Responsib. Environ. Manag. 2018, 25, 1143-1153. [CrossRef]

7. Aust, I.; Muller-Camen, M.; Poutsma, E. Sustainable HRM: A comparative and international perspective. In Handbook of Research on Comparative Human Resource Management; Brewster, C., Farndale, E., Mayrhofer, W., Eds.; Edward Elgar Publishing: Cheltenham, UK, 2018; pp. 358-369.

8. Cooke, F.L.; He, Q. Corporate social responsibility and HRM in China: A study of textile and apparel enterprises. Asia Pac. Bus. Rev. 2010, 16, 355-376. [CrossRef]

9. Turker, D. Measuring Corporate Social Responsibility: A Scale Development Study. J. Bus. Ethics 2009, 85, 411-427. [CrossRef]

10. Aharon, T.; Lior, O.; Yaki, B.; Gal, K. Corporate Social Responsibility, Organizational Justice and Job Satisfaction: How do They Interrelate, If at All? Rev. Psicol. Trab. Las Organ. 2011, 27, 67-72. [CrossRef]

11. Valentine, S.; Fleischman, G. Ethics Programs, Perceived Corporate Social Responsibility and Job Satisfaction. J. Bus. Ethics 2008, 77, 159-172. [CrossRef]

12. You, C.-S.; Huang, C.-C.; Wang, H.-B.; Liu, K.-N.; Lin, C.-H.; Tseng, J.-S. The relationship between corporate social responsibility, job satisfaction, and organizational commitment. Int. J. Organ. Innov. 2013, 5, 65-77.

13. Ali, I.; Rehman, K.U.; Ali, S.I.; Yousaf, J.; Zia, M. Corporate social responsibility influences, employee commitment and organizational performance. Afr. J. Bus. Manag. 2010, 4, 2796-2801.

14. Brammer, S.; Millington, A.; Rayton, B. The contribution of corporate social responsibility to organizational commitment. Int. J. Hum. Resour. Manag. 2007, 18, 1701-1719. [CrossRef]

15. Ebeid, A.Y.H. Corporate social responsibility and its relation to organizational commitment. Probl. Perspect. Manag. 2010, 8, 76-83.

16. Maignan, I.; Ferrell, O. Antecedents and benefits of corporate citizenship: An investigation of French businesses. J. Bus. Res. 2001, 51, 37-51. [CrossRef]

17. Maignan, I.; Ferrell, O.C.; Hult, G.T.M. Corporate Citizenship: Cultural Antecedents and Business Benefits. J. Acad. Mark. Sci. 1999, 27, 455-469. [CrossRef]

18. Peterson, D.K. The Relationship between Perceptions of Corporate Citizenship and Organizational Commitment. Bus. Soc. 2004, 43, 296-319. [CrossRef]

19. Aguilera, R.V.; Rupp, D.E.; Williams, C.A.; Ganapathi, J. Putting the S back in corporate social responsibility: A multilevel theory of social change in organizations. Acad. Manag. Rev. 2007, 32, 836-863. [CrossRef]

20. Organ, D.W. Organizational Citizenship Behavior: The Good Soldier Syndrome; Lexington Books: Lexington, MA, USA, 1988. 
21. Story, J.S.P.; Castanheira, F. Corporate social responsibility and employee performance: Mediation role of job satisfaction and affective commitment. Corp. Soc. Responsib. Environ. Manag. 2019, 26, csr.1752. [CrossRef]

22. Lu, X.; Zhu, W.; Tsai, F.-S. Social Responsibility toward the Employees and Career Development Sustainability during Manufacturing Transformation in China. Sustainability 2019, 11, 4778. [CrossRef]

23. López-Fernández, M.; Romero-Fernández, P.M.; Aust, I. Socially Responsible Human Resource Management and Employee Perception: The Influence of Manager and Line Managers. Sustainability 2018, 10, 4614. [CrossRef]

24. Appelbaum, E.; Bailey, T.; Berg, P.; Kalleberg, A.L. Do high performance work systems pay off? In The Transformation of Work (Research in the Sociology of Work); Vallas, S., Ed.; Emerald Group Publishing Limited: Bingley, UK, 2001; Volume 10, pp. 85-107.

25. Huselid, M.A. The impact of Human Resource Management Practices on Turnover, Productivity, and Corporate Financial Performance. Acad. Manag. J. 1995, 38, 635-672. [CrossRef]

26. Jiang, K.; Lepak, D.P.; Hu, J.; Baer, J.C. How Does Human Resource Management Influence Organizational Outcomes? A Meta-analytic Investigation of Mediating Mechanisms. Acad. Manag. J. 2012, 55, 1264-1294. [CrossRef]

27. Knies, E.; Leisink, P. Linking people management and extra-role behaviour: Results of a longitudinal study. Hum. Resour. Manag. J. 2014, 24, 57-76. [CrossRef]

28. European Commission. Next Steps for a Sustainable European Future-European Action for Sustainability: Questions E Answers; European Commission: Belgium, Brussels, 2016; Available online: https:/europa.eu/ rapid/press-release_MEMO-16-3886_en.htm (accessed on 19 december 2019).

29. The World Commission on Environment and Development. Brundtlan Report. Report of the World Commission on Environment and Development: Our Common Future. 1987. Available online: https://sustainabledevelopment. un.org/content/documents/5987our-common-future.pdf (accessed on 19 december 2019).

30. The Sustainability Yearbook 2008; SAM \& PricewaterhouseCoopers: Zurich, Switzerland, 2008.

31. Ehnert, I.; Parsa, S.; Roper, I.; Wagner, M.; Muller-Camen, M. Reporting on sustainability and HRM: A comparative study of sustainability reporting practices by the world's largest companies. Int. J. Hum. Resour. Manag. 2016, 27, 88-108. [CrossRef]

32. Mandip, G. Green HRM-People Management Commitment to Environmental Sustainability. Res. J. Recent Sci. 2012, 1, 244-252.

33. Gholami, H.; Rezaei, G.; Saman, M.Z.M.; Sharif, S.; Zakuan, N. State-of-the-art Green HRM System: Sustainability in the sports center in Malaysia using a multi-methods approach and opportunities for future research. J. Clean. Prod. 2016, 124, 142-163. [CrossRef]

34. Kramar, R. Beyond strategic human resource management: Is sustainable human resource management the next approach? Int. J. Hum. Resour. Manag. 2014, 25, 1069-1089. [CrossRef]

35. Mariappanadar, S. A conceptual framework for cost measures of harm of HRM practices. Asia-Pac. J. Bus. Adm. 2013, 5, 103-114. [CrossRef]

36. Masri, H.A.; Jaaron, A.A.M. Assessing green human resources management practices in Palestinian manufacturing context: An empirical study. J. Clean. Prod. 2017, 143, 474-489. [CrossRef]

37. Renwick, D.W.S.; Redman, T.; Maguire, S. Green Human Resource Management: A Review and Research Agenda. Int. J. Manag. Rev. 2013, 15, 1-14. [CrossRef]

38. Ren, S.; Tang, G.; Jackson, S.E. Green human resource management research in emergence: A review and future directions. Asia Pac. J. Manag. 2018, 35, 769-803. [CrossRef]

39. Cobo, M.J.; López-Herrera, A.G.; Herrera-Viedma, E.; Herrera, F. An approach for detecting, quantifying, and visualizing the evolution of a research field: A practical application to the Fuzzy Sets Theory field. J. Informetr. 2011, 5, 146-166. [CrossRef]

40. Cobo, M.J.; López-Herrera, A.G.; Herrera-Viedma, E.; Herrera, F. Science mapping software tools: Review, analysis, and cooperative study among tools. J. Am. Soc. Inf. Sci. Technol. 2011, 62, 1382-1402. [CrossRef]

41. Small, H. Visualizing science by citation mapping. J. Am. Soc. Inf. Sci. 1999, 50, 799-813. [CrossRef]

42. Cobo, M.J.; López-Herrera, A.G.; Herrera-Viedma, E.; Herrera, F. SciMAT: A new science mapping analysis software tool. J. Am. Soc. Inf. Sci. Technol. 2012, 63, 1609-1630. [CrossRef]

43. Batagelj, V.; Cerinšek, M. On bibliographic networks. Scientometrics 2013, 96, 845-864. [CrossRef]

44. Börner, K.; Chen, C.; Boyack, K.W. Visualizing knowledge domains. Annu. Rev. Inf. Sci. Technol. 2005, 37, 179-255. [CrossRef] 
45. Alcaide-Muñoz, L.; Rodríguez-Bolívar, M.P.; Cobo, M.J.; Herrera-Viedma, E. Analysing the scientific evolution of e-Government using a science mapping approach. Gov. Inf. Q. 2017, 34, 545-555. [CrossRef]

46. Norris, M.; Oppenheim, C. Comparing alternatives to the Web of Science for coverage of the social sciences' literature. J. Informetr. 2007, 1, 161-169. [CrossRef]

47. Sánchez, A.D.; de la Cruz Del Río Rama, M.; García, J.Á. Bibliometric analysis of publications on wine tourism in the databases Scopus and WoS. Eur. Res. Manag. Bus. Econ. 2017, 23, 8-15. [CrossRef]

48. Coulter, N.; Monarch, I.; Konda, S. Software engineering as seen through its research literature: A study in co-word analysis. J. Am. Soc. Inf. Sci. 1998, 49, 1206-1223. [CrossRef]

49. Callon, M.; Courtial, J.-P.; Turner, W.A.; Bauin, S. From translations to problematic networks: An introduction to co-word analysis. Soc. Sci. Inf. 1983, 22, 191-235. [CrossRef]

50. Callon, M.; Courtial, J.P.; Laville, F. Co-word analysis as a tool for describing the network of interactions between basic and technological research: The case of polymer chemsitry. Scientometrics 1991, 22, 155-205. [CrossRef]

51. Orlitzky, M.; Swanson, D.L. Socially responsible human resource management. In Human Resource Management Ethics; Information Age Publishing: Charlotte, NC, USA, 2006; pp. 3-25. ISBN 9781607525684.

52. Newman, A.; Miao, Q.; Hofman, P.S.; Zhu, C.J. The impact of socially responsible human resource management on employees' organizational citizenship behaviour: The mediating role of organizational identification. Int. J. Hum. Resour. Manag. 2016, 27, 440-455. [CrossRef]

53. Shen, J.; Jiuhua Zhu, C. Effects of socially responsible human resource management on employee organizational commitment. Int. J. Hum. Resour. Manag. 2011, 22, 3020-3035. [CrossRef]

54. Jackson, S.E.; Renwick, D.W.S.; Jabbour, C.J.C.; Muller-Camen, M. State-of-the-Art and Future Directions for Green Human Resource Management: Introduction to the Special Issue. Ger. J. Hum. Resour. Manag. 2011, 25, 99-116. [CrossRef]

55. Renwick, D.; Redman, T.; Maguire, S. Green HRM: A review, process model, and research agenda. Discuss. Pap. Univ. Sheff. Manag. Sch. 2008, 44, 1-46.

56. Ehnert, I.; Wes, H.E. Recent Developments and Future Prospects on Sustainable Human Resource Management: Introduction to the Special Issue. Manag. Rev. 2012, 23, 221-238. [CrossRef]

57. Ehnert, I. Conceptual Model for Sustainable HRM and a Paradox Framework. In Sustainable Human Resource Management; Physica-Verlag: Heidelberg, Germany, 2009; pp. 163-181.

58. Wilkinson, A.; Hill, M.; Gollan, P. The sustainability debate. Int. J. Oper. Prod. Manag. 2001, 21, 1492-1502. [CrossRef]

59. Bučiūnienè, I.; Kazlauskaitė, R. The linkage between HRM, CSR and performance outcomes. Balt. J. Manag. 2012, 7, 5-24. [CrossRef]

60. Lis, B. The Relevance of Corporate Social Responsibility for a Sustainable Human Resource Management: An Analysis of Organizational Attractiveness as a Determinant in Employees' Selection of a (Potential) Employer. Manag. Rev. 2012, 23, 279-295. [CrossRef]

61. Carroll, A.B. The pyramid of corporate social responsibility: Toward the moral management of organizational stakeholders. Bus. Horiz. 1991, 34, 39-48. [CrossRef]

62. Del Baldo, M. Corporate social responsibility, human resource management and corporate family responsibility. When a company is "the best place to work": Elica group, the hi-life company. Ekon. Istraz. 2013, 26, 201-224. [CrossRef]

63. Del Brío, J.Á.; Fernández, E.; Junquera, B. Management and employee involvement in achieving an environmental action-based competitive advantage: An empirical study. Int. J. Hum. Resour. Manag. 2007, 18, 491-522. [CrossRef]

64. Jabbour, C.J.C.; Jabbour, A.B.L.; Teixeira, A.A.; Freitas, W.R.S. Environmental development in Brazilian companies: The role of human resource management. Environ. Dev. 2012, 3, 137-147. [CrossRef]

65. Wagner, M. Environmental Management Activities and Sustainable HRM in German Manufacturing Firms-Incidence, Determinants, and Outcomes. Ger. J. Hum. Resour. Manag. Z. Pers. 2011, 25, 157-177. [CrossRef]

66. Shen, J.; Benson, J. When CSR Is a Social Norm. J. Manag. 2016, 42, 1723-1746. [CrossRef]

67. Paillé, P.; Chen, Y.; Boiral, O.; Jin, J. The Impact of Human Resource Management on Environmental Performance: An Employee-Level Study. J. Bus. Ethics 2014, 121, 451-466. [CrossRef] 
68. Boiral, O.; Paillé, P. Organizational Citizenship Behaviour for the Environment: Measurement and Validation. J. Bus. Ethics 2012, 109, 431-445. [CrossRef]

69. De Prins, P.; Van Beirendonck, L.; De Vos, A.; Segers, J. Sustainable HRM: Bridging theory and practice through the 'Respect Openness Continuity (ROC)'-model. Manag. Rev. 2014, 25, 263-284. [CrossRef]

70. Mariappanadar, S. Health harm of work from the sustainable HRM perspective: Scale development and validation. Int. J. Manpow. 2016, 37, 924-944. [CrossRef]

71. Jabbour, C.J.C.; de Sousa Jabbour, A.B.L. Green Human Resource Management and Green Supply Chain Management: Linking two emerging agendas. J. Clean. Prod. 2016, 112, 1824-1833. [CrossRef]

72. Guerci, M.; Longoni, A.; Luzzini, D. Translating stakeholder pressures into environmental performance-The mediating role of green HRM practices. Int. J. Hum. Resour. Manag. 2016. [CrossRef]

73. Lee, J.; Maxfield, S. Doing Well by Reporting Good: Reporting Corporate Responsibility and Corporate Performance. Bus. Soc. Rev. 2015, 120, 577-606. [CrossRef]

74. Milfelner, B.; Potočnik, A.; Žižek, S.Š. Social Responsibility, Human Resource Management and Organizational Performance. Syst. Res. Behav. Sci. 2015, 32, 221-229. [CrossRef]

75. Pellegrini, C.; Rizzi, F.; Frey, M. The role of sustainable human resource practices in influencing employee behavior for corporate sustainability. Bus. Strateg. Environ. 2018, 27, 1221-1232. [CrossRef]

76. Wang, C.-J. Linking Sustainable Human Resource Management in Hospitality: An Empirical Investigation of the Integrated Mediated Moderation Model. Sustainability 2019, 11, 1066. [CrossRef]

77. Santana, M.; Lopez-Cabrales, Á. Sustainable development and human resource management: A science mapping approach. Corp. Soc. Responsib. Environ. Manag. 2019, 26, 1171-1183. [CrossRef]

78. Stankevičiūtè, Ž.; Savanevičienè, A. Raising the Curtain in People Management by Exploring How Sustainable HRM Translates to Practice: The Case of Lithuanian Organizations. Sustainability 2018, 10, 4356. [CrossRef]

79. Longoni, A.; Luzzini, D.; Guerci, M. Deploying Environmental Management Across Functions: The Relationship Between Green Human Resource Management and Green Supply Chain Management. J. Bus. Ethics 2018, 151, 1081-1095. [CrossRef]

80. Dumont, J.; Shen, J.; Deng, X. Effects of Green HRM Practices on Employee Workplace Green Behavior: The Role of Psychological Green Climate and Employee Green Values. Hum. Resour. Manag. 2017, 56, 613-627. [CrossRef]

81. Saeed, B.B.; Afsar, B.; Hafeez, S.; Khan, I.; Tahir, M.; Afridi, M.A. Promoting employee's proenvironmental behavior through green human resource management practices. Corp. Soc. Responsib. Environ. Manag. 2019, 26, 424-438. [CrossRef]

82. Shen, J.; Zhang, H. Socially Responsible Human Resource Management and Employee Support for External CSR: Roles of Organizational CSR Climate and Perceived CSR Directed Toward Employees. J. Bus. Ethics 2019, 156, 875-888. [CrossRef]

83. Shao, D.; Zhou, E.; Gao, P. Influence of Perceived Socially Responsible Human Resource Management on Task Performance and Social Performance. Sustainability 2019, 11, 3195. [CrossRef]

84. Shao, D.; Zhou, E.; Gao, P.; Long, L.; Xiong, J. Double-Edged Effects of Socially Responsible Human Resource Management on Employee Task Performance and Organizational Citizenship Behavior: Mediating by Role Ambiguity and Moderating by Prosocial Motivation. Sustainability 2019, 11, 2271. [CrossRef]

85. Diaz-Carrion, R.; López-Fernández, M.; Romero-Fernandez, P.M. Evidence of different models of socially responsible HRM in Europe. Bus. Ethics A Eur. Rev. 2019, 28, 1-18. [CrossRef]

86. Lopez-Fernandez, M.; Romero-Fernandez, P.M. Special Issue: Instruments for Measuring Corporate Social Responsibility (CSR): The Special Case of Human Resource Management (HRM). Sustainability 2020, in press.

87. Cugueró-Escofet, N.; Ficapal-Cusí, P.; Torrent-Sellens, J. Sustainable Human Resource Management: How to Create a Knowledge Sharing Behavior through Organizational Justice, Organizational Support, Satisfaction and Commitment. Sustainability 2019, 11, 5419. [CrossRef]

88. Aselage, J.; Eisenberger, R. Perceived Organizational Support and Psychological Contracts: A Theoretical Integration. J. Organ. Behav. 2003, 24, 491-509. [CrossRef]

89. Eisenberger, R.; Huntington, R.; Hutchison, S.; Sowa, D. Perceived Organizational Support. J. Appl. Psychol. 1986, 71, 500-507. [CrossRef]

90. Shen, J.; Dumont, J.; Deng, X. Employees' Perceptions of Green HRM and Non-Green Employee Work Outcomes: The Social Identity and Stakeholder Perspectives. Group Organ. Manag. 2018, 43, 594-622. [CrossRef] 
91. Lechuga Sancho, M.P.; Martínez-Martínez, D.; Larran Jorge, M.; Herrera Madueño, J. Understanding the link between socially responsible human resource management and competitive performance in SMEs. Pers. Rev. 2018, 47, 1211-1243. [CrossRef]

92. Berber, N.; Susnjar, G.S.; Slavic, A.; Baosic, M. Relationship between Corporate Social Responsibility and Human Resource Management-As new management concepts-In Central and Eastern Europe. Eng. Econ. 2014, 25, 360-369. [CrossRef]

93. Mariappanadar, S.; Kramar, R. Sustainable HRM. Asia-Pac. J. Bus. Adm. 2014, 6, 206-224. [CrossRef]

94. Järlström, M.; Saru, E.; Vanhala, S. Sustainable Human Resource Management with Salience of Stakeholders: A Top Management Perspective. J. Bus. Ethics 2018, 152, 703-724. [CrossRef]

95. Weng, Q.X. The Impact Mechanism of Career Growth on Employees' Commitment and Turnover. Ph.D. Thesis, Huazhong University of Science and Technology, Hangzhou, China, 2009. (In Chinese).

96. Rothwell, A.; Arnold, J. Self-perceived employability: Development and validation of a scale. Pers. Rev. 2007, 36, 23-41. [CrossRef]

97. Madjar, N.; Greenberg, E.; Chen, Z. Factors for radical creativity, incremental creativity, and routine, noncreative performance. J. Appl. Psychol. 2011, 96, 730-743. [CrossRef]

98. Aibaghi Esfahani, S.; Rezaii, H.; Koochmeshki, N.; Sharifi Parsa, S. Sustainable and flexible human resource management for innovative organizations. AD-Minister 2017, 195-215. [CrossRef]

99. Ramus, C.A. Organizational Support for Employees: Encouraging Creative Ideas for Environmental Sustainability. Calif. Manag. Rev. 2001, 43, 85-105. [CrossRef]

100. Lytle, R.S.; Hom, P.W.; Mokwa, M.P. SERV*OR: A managerial measure of organizational service-orientation. J. Retail. 1998, 74, 455-489. [CrossRef]

101. Strenitzerová, M.; Achimský, K. Employee Satisfaction and Loyalty as a Part of Sustainable Human Resource Management in Postal Sector. Sustainability 2019, 11, 4591. [CrossRef]

102. Manzoor, F.; Wei, L.; Bányai, T.; Nurunnabi, M.; Subhan, Q.A. An Examination of Sustainable HRM Practices on Job Performance: An Application of Training as a Moderator. Sustainability 2019, 11, 2263. [CrossRef]

103. Obrad, C.; Gherhes, V. A Human Resources Perspective on Responsible Corporate Behavior. Case Study: The Multinational Companies in Western Romania. Sustainability 2018, 10, 726. [CrossRef]

104. Nie, D.; Lämsä, A.-M.; Pučètaite, R. Effects of responsible human resource management practices on female employees' turnover intentions. Bus. Ethics A Eur. Rev. 2018, 27, 29-41. [CrossRef]

105. Barrena-Martínez, J.; López-Fernández, M.; Romero-Fernandez, P. Drivers and Barriers in Socially Responsible Human Resource Management. Sustainability 2018, 10, 1532. [CrossRef]

106. Bombiak, E.; Marciniuk-Kluska, A. Green Human Resource Management as a Tool for the Sustainable Development of Enterprises: Polish Young Company Experience. Sustainability 2018, 10, 1739. [CrossRef]

107. Jabbour, C.J.C.; Santos, F.C.A.; Nagano, M.S. Contributions of HRM throughout the stages of environmental management: Methodological triangulation applied to companies in Brazil. Int. J. Hum. Resour. Manag. 2010, 21, 1049-1089. [CrossRef]

108. Zibarras, L.D.; Coan, P. HRM practices used to promote pro-environmental behavior: A UK survey. Int. J. Hum. Resour. Manag. 2015, 26, 2121-2142. [CrossRef]

109. Zhang, Y.; Luo, Y.; Zhang, X.; Zhao, J. How Green Human Resource Management Can Promote Green Employee Behavior in China: A Technology Acceptance Model Perspective. Sustainability 2019, 11, 5408. [CrossRef]

110. O'Donohue, W.; Torugsa, N.A. The moderating effect of 'Green' HRM on the association between proactive environmental management and financial performance in small firms. Int. J. Hum. Resour. Manag. 2016, 27, 239-261. [CrossRef]

111. Chaudhary, R. Green Human Resource Management and Employee Green Behavior: An Empirical Analysis. Corp. Soc. Responsib. Environ. Manag. 2019, csr.1827. [CrossRef]

112. Ahmad, I.; Umrani, W.A. The impact of ethical leadership style on job satisfaction. Leadersh. Organ. Dev. J. 2019, 40, 534-547. [CrossRef]

113. Tang, G.; Chen, Y.; Jiang, Y.; Paillé, P.; Jia, J. Green human resource management practices: Scale development and validity. Asia Pac. J. Hum. Resour. 2018, 56, 31-55. [CrossRef]

114. Bombiak, E. Green human resource management-The latest trend or strategic necessity? Entrep. Sustain. Issues 2019, 6, 1647-1662. [CrossRef] 
115. Shah, M. Green human resource management: Development of a valid measurement scale. Bus. Strateg. Environ. 2019, 28, 771-785. [CrossRef]

116. Chou, C.J. Hotels' environmental policies and employee personal environmental beliefs: Interactions and outcomes. Tour. Manag. 2014, 40, 436-446. [CrossRef]

117. Kaiser, F.G.; Oerke, B.; Bogner, F.X. Behavior-based environmental attitude: Development of an instrument for adolescents. J. Environ. Psychol. 2007, 27, 242-251. [CrossRef]

118. Kim, S.-H.; Kim, M.; Han, H.-S.; Holland, S. The determinants of hospitality employees' pro-environmental behaviors: The moderating role of generational differences. Int. J. Hosp. Manag. 2016, 52, 56-67. [CrossRef]

119. Robertson, J.L.; Barling, J. Greening organizations through leaders' influence on employees' pro-environmental behaviors. J. Organ. Behav. 2013, 34, 176-194. [CrossRef]

120. Paillé, P.; Boiral, O.; Chen, Y. Linking environmental management practices and organizational citizenship behaviour for the environment: A social exchange perspective. Int. J. Hum. Resour. Manag. 2013, 24, 3552-3575. [CrossRef]

121. Paillé, P.; Raineri, N. Trust in the context of psychological contract breach: Implications for environmental sustainability. J. Environ. Psychol. 2016, 45, 210-220. [CrossRef]

122. Priyankara, H.; Luo, F.; Saeed, A.; Nubuor, S.; Jayasuriya, M. How Does Leader's Support for Environment Promote Organizational Citizenship Behaviour for Environment? A Multi-Theory Perspective. Sustainability 2018, 10, 271. [CrossRef]

123. Pinzone, M.; Guerci, M.; Lettieri, E.; Huisingh, D. Effects of 'green' training on pro-environmental behaviors and job satisfaction: Evidence from the Italian healthcare sector. J. Clean. Prod. 2019, 226, 221-232. [CrossRef]

124. Bissing-Olson, M.J.; Iyer, A.; Fielding, K.S.; Zacher, H. Relationships between daily affect and proenvironmental behavior at work: The moderating role of pro-environmental attitude. J. Organ. Behav. 2013, 34, 156-175. [CrossRef]

125. Frese, M.; Fay, D.; Hilburger, T.; Leng, K.; Tag, A. The concept of personal initiative: Operationalization, reliability and validity in two German samples. J. Occup. Organ. Psychol. 1997, 70, 139-161. [CrossRef]

126. Norton, T.A.; Zacher, H.; Ashkanasy, N.M. Organisational sustainability policies and employee green behaviour: The mediating role of work climate perceptions. J. Environ. Psychol. 2014, 38, 49-54. [CrossRef]

127. Graves, L.M.; Sarkis, J.; Zhu, Q. How transformational leadership and employee motivation combine to predict employee proenvironmental behaviors in China. J. Environ. Psychol. 2013, 35, 81-91. [CrossRef]

128. Lamm, E.; Tosti-Kharas, J.; Williams, E.G. Read This Article, but Don't Print It. Group Organ. Manag. 2013, 38, 163-197. [CrossRef]

129. Islam, T.; Ali, G.; Asad, H. Environmental CSR and pro-environmental behaviors to reduce environmental dilapidation. Manag. Res. Rev. 2019, 42,332-351. [CrossRef]

130. Markle, G.L. Pro-Environmental Behavior: Does It Matter How It's Measured? Development and Validation of the Pro-Environmental Behavior Scale (PEBS). Hum. Ecol. 2013, 41, 905-914. [CrossRef]

131. Prati, G.; Albanesi, C.; Pietrantoni, L. The interplay among environmental attitudes, pro-environmental behavior, social identity, and pro-environmental institutional climate. A longitudinal study. Environ. Educ. Res. 2017, 23, 176-191. [CrossRef]

132. Kim, A.; Kim, Y.; Han, K.; Jackson, S.E.; Ployhart, R.E. Multilevel Influences on Voluntary Workplace Green Behavior: Individual Differences, Leader Behavior, and Coworker Advocacy. J. Manag. 2017, 43, 1335-1358. [CrossRef]

133. Norton, T.A.; Zacher, H.; Parker, S.L.; Ashkanasy, N.M. Bridging the gap between green behavioral intentions and employee green behavior: The role of green psychological climate. J. Organ. Behav. 2017, 38, 996-1015. [CrossRef]

134. Xing, Y.; Starik, M. Taoist leadership and employee green behaviour: A cultural and philosophical microfoundation of sustainability. J. Organ. Behav. 2017, 38, 1302-1319. [CrossRef]

135. Bohlmann, C.; van den Bosch, J.; Zacher, H. The relative importance of employee green behavior for overall job performance ratings: A policy-capturing study. Corp. Soc. Responsib. Environ. Manag. 2018, 25, 1002-1008. [CrossRef]

136. Rayner, J.; Morgan, D. An empirical study of 'green' workplace behaviours: Ability, motivation and opportunity. Asia Pac. J. Hum. Resour. 2018, 56, 56-78. [CrossRef]

137. Zoogah, D.B. High-performance organizing, environmental management, and organizational performance: An evolutionary economics perspective. Hum. Resour. Manag. 2018, 57, 159-175. [CrossRef] 
138. Paillé, P.; Mejía Morelos, J.H.; Raineri, N.; Stinglhamber, F. The Influence of the Immediate Manager on the Avoidance of Non-green Behaviors in the Workplace: A Three-Wave Moderated-Mediation Model. J. Bus. Ethics 2019, 155, 723-740. [CrossRef]

139. Zhang, S.; Wang, Z.; Zhao, X. Effects of proactive environmental strategy on environmental performance: Mediation and moderation analyses. J. Clean. Prod. 2019, 235, 1438-1449. [CrossRef]

140. Rao, P.; Holt, D. Do green supply chains lead to competitiveness and economic performance? Int. J. Oper. Prod. Manag. 2005, 25, 898-916. [CrossRef]

141. González, P.; Sarkis, J.; Adenso-Díaz, B. Environmental management system certification and its influence on corporate practices. Int. J. Oper. Prod. Manag. 2008, 28, 1021-1041. [CrossRef]

142. Martínez, M.A.; Cobo, M.J.; Herrera, M.; Herrera-Viedma, E. Analyzing the Scientific Evolution of Social Work Using Science Mapping. Res. Soc. Work Pract. 2015, 25, 257-277. [CrossRef]

143. Moral-Munoz, J.A.; Carballo-Costa, L.; Herrera-Viedma, E.; Cobo, M.J. Production Trends, Collaboration, and Main Topics of the Integrative and Complementary Oncology Research Area: A Bibliometric Analysis. Integr. Cancer Ther. 2019, 18, 1-14. [CrossRef] [PubMed]

(C) 2020 by the authors. Licensee MDPI, Basel, Switzerland. This article is an open access article distributed under the terms and conditions of the Creative Commons Attribution (CC BY) license (http://creativecommons.org/licenses/by/4.0/). 